\title{
Evolutionary dynamics of emblematic Araucaria species (Araucariaceae) in New Caledonia: nuclear and chloroplast markers suggest recent diversification, introgression, and a tight link between genetics and geography within species
}

Myriam Gaudeul ${ }^{1 *}$, Martin F Gardner ${ }^{2}$, Philip Thomas ${ }^{2}$, Richard A Ennos ${ }^{3}$ and Pete M Hollingsworth ${ }^{2}$

\begin{abstract}
Background: New Caledonia harbours a highly diverse and endemic flora, and 13 (out of the 19 worldwide) species of Araucaria are endemic to this territory. Their phylogenetic relationships remain largely unresolved. Using nuclear microsatellites and chloroplast DNA sequencing, we focused on five closely related Araucaria species to investigate among-species relationships and the distribution of within-species genetic diversity across New Caledonia.

Results: The species could be clearly distinguished here, except A. montana and A. laubenfelsii that were not differentiated and, at most, form a genetic cline. Given their apparent morphological and ecological similarity, we suggested that these two species may be considered as a single evolutionary unit. We observed cases of nuclear admixture and incongruence between nuclear and chloroplast data, probably explained by introgression and shared ancestral polymorphism. Ancient hybridization was evidenced between A. biramulata and A. laubenfelsii in Mt Do, and is strongly suspected between A. biramulata and A. rulei in Mt Tonta. In both cases, extensive asymmetrical backcrossing eliminated the influence of one parent in the nuclear DNA composition. Shared ancestral polymorphism was also observed for cpDNA, suggesting that species diverged recently, have large effective sizes and/or that cpDNA experienced slow rates of molecular evolution. Within-species genetic structure was pronounced, probably because of low gene flow and significant inbreeding, and appeared clearly influenced by geography. This may be due to survival in distinct refugia during Quaternary climatic oscillations.
\end{abstract}

Conclusions: The study species probably diverged recently and/or are characterized by a slow rate of cpDNA sequence evolution, and introgression is strongly suspected. Within-species genetic structure is tightly linked with geography. We underline the conservation implications of our results, and highlight several perspectives.

Keywords: Admixture, Closely related species, Conifers, Diversification, Hotspot, Hybridization, Introgression, Phylogeography, Population genetics, Systematics

\footnotetext{
* Correspondence: gaudeul@mnhn.fr

'UMR CNRS-MNHN-UPMC-EPHE 7205 Institut de Systématique, Evolution, Biodiversité', Muséum National d'Histoire Naturelle, 16 rue Buffon, CP 39, F-75005 Paris, France

Full list of author information is available at the end of the article
} 


\section{Background}

Over the last decades, both theoretical and empirical investigations have underlined the continuum of evolutionary processes acting on populations and species (e.g. [1-5]). Therefore, an increasing number of studies adopt an integrative approach and combine concepts, molecular techniques and statistical tools from both areas to shed light on the evolutionary dynamics of closely related species. In such groups, species may undergo a process of divergence (with population differentiation as the first step) and reproductive isolation and, in different places or at different times, may exchange genes through hybridization and introgression if reproductive isolation is not complete. The speciation process lies at the heart of this interface between population genetics and phylogenetics, with many questions that remain unanswered in most cases e.g. when and why did populations initially diverge? What were their relative geographic distributions (sympatry vs. allopatry)? How did reproductive isolation emerge? Such questions are crucial challenges faced by biologists to understand the evolution of species, and to better preserve the mechanisms generating diversity in the face of today's major environmental threats.

New Caledonia is a biodiversity hotspot [6] with more than 3000 native angiosperm and 43 conifer species in an area of ca. $19000 \mathrm{~km} 2$. It is characterized by high endemism (77\% for angiosperms and 100\% for conifers; [7]). Although it is of continental Gondwanan origin and geographically isolated ( $1500 \mathrm{~km}$ east of Australia), recent studies have shown that the modern New Caledonian biodiversity largely originates from dispersal events and in situ species radiations [8,9]. This is congruent with the long submersion of the island (ca. 65-37 Ma; $[10,11]$ ), and radiations were probably favoured by environmental gradients -notably in terms of soil substrate, altitude and climate- which have created a variety of habitats within a small geographic area. Also, in contrast to what was long supposed given the old separation of New Caledonia from Australia (ca. $80 \mathrm{Ma}$; [11]) and congruent with the submersion of the island, most radiations would be relatively recent $(<15 \mathrm{Ma}$; reviewed in $[12,13])$. In this context, studies at the interface between population genetics and phylogenetics seem best suited to examine how the biodiversity of New Caledonia emerged. However, to date, most investigations have dealt with taxonomy and largescale phylogeny (e.g. [14-17]) -reflecting our very incomplete knowledge of the flora and fauna and justified by the strong pressure of habitat destruction due to human-set fires and open-cast mining activities $[18,19]$. Only a few plant studies have examined relationships among closely related species [20-24] or surveyed the distribution of within-species genetic diversity on the island, with the latter often focused on a low number of populations or small geographic area [25-30]. Yet, surveys of population genetics also provide information on the recent history and could be useful to detect the possible impacts of the Quaternary climatic oscillations experienced by the New Caledonian flora: in the southeast of the island, palynological records suggested that vegetation alternated between rainforest and maquis from 120,000 to $50,000 \mathrm{yr}$ ago, and a compelling Araucaria decline was detected around 45,000 yr ago [31]. However, the location of potential refugia remains highly uncertain (but see [30,32]). Populations that originate from the same refugia are expected to form a genetically more or less homogeneous group compared to populations that colonized from distinct refugia [33]. Nevertheless, given the complex topology of the island, with many physical barriers, genetic drift could have a strong influence on the genetic structure relative to current gene flow, and cause significant differentiation among populations.

Here, we studied species of the conifer genus Araucaria Juss. (Araucariaceae) and were both interested in amongspecies relationships and the distribution of within-species genetic diversity across New Caledonia. The genus Araucaria comprises a total of 19 species worldwide, 13 of which are endemic to the archipelago. They usually occur as large populations, in a variety of ecological habitats (most often humid forest or maquis; [34]). Importantly, all species are confined to ultramafic soils -characterized by low fertility (low N, P, K), high concentrations of heavy metals (e.g., $\mathrm{Co}, \mathrm{Cr}, \mathrm{Ni}$ ) and low water-holding capacity [35]- except A. montana Brongn. \& Gris, which occurs on both ultramafic and non-ultramafic soils and A. columnaris Hook. and A. schmidii de Laub., which only occur on calcareous and acidic soils, respectively. Araucaria trees are long-lived, monoecious trees whose breeding system is largely unknown. Pollen dispersal is wind-mediated and probably larger than seed dispersal, which mainly occurs by gravity. However, secondary seed dispersal by animals and strong winds is likely since they possess wings and ripen during the cyclone season [36].

Based on rbcL sequencing, Setoguchi et al. [37] showed that New Caledonian Araucaria species form a monophyletic group and, using AFLP markers, Gaudeul et al. [34] delineated three clades within this group: the large-leaved, small-leaved and coastal clades. Nevertheless, the exact relationships among species remain unresolved, especially within the large-leaved group that includes six species: A. montana, A. laubenfelsii Corbasson, A. rulei F.Muell., A. biramulata J. Buchholz, A. muelleri (Carrière) Brong. \& Gris and $A$. humboldtensis J. Buchholz. In addition, the distinction of $A$. montana and A. laubenfelsii-described in 1871 and 1968, respectively [38]- was questioned by field observations: they have very similar morphology and ecology and their distribution areas are contiguous, with A. montana being found in the north while A. laubenfelsii is restricted to some localities in the south. As for many 
New Caledonian plant species, several Araucaria populations/species are threatened by habitat destruction $[28,39]$. However, the reduction of suitable habitat and population size has probably not left any signature in the genetic structure of today adult populations, because Araucaria trees are very long-lived (> 500 years; [40]) and habitat destruction comparatively recent (starting in 1874; [39]). Consequently, most adult trees observed today existed before the beginning of habitat destruction, and there has been little opportunity for changes in genetic structure of remaining populations since then. Previous genetic surveys on New Caledonian Araucaria species focused on the highly threatened and geographically restricted A. nemorosa and its widespread relative A. columnaris $[28,41,42]$. These studies covered a small geographic area, and were primarily aimed at providing practical information for conservation.

We examined the genetic structure of four species that are largely distributed in New Caledonia: A. montana and $A$. laubenfelsii (which may form a single species), $A$. rulei, and $A$. scopulorum (which belongs to the coastal clade whereas the other three belong to the large-leaved clade). Also, some species sometimes grow sympatrically and we suspected introgression, which may account for the difficulty to resolve the species phylogeny. Since A. biramulata may be involved in such events based on our field observations (intermediate morphology and unusual ecology of a given population, in Mt Tonta), it was also surveyed here. Ancient hybridization events and introgression may be detected through genetic admixture at nuclear loci (see e.g. [43]), or through incongruent genealogical patterns between uniparental and nuclear DNA (e.g. [3]). The retention of ancestral polymorphism, or 'incomplete lineage sorting', can lead to similar incongruence and disentangling the two phenomena -that are both more likely among closely related than anciently diverged species- is sometimes difficult (see e.g. [5,43-45] and references therein). Retention of ancestral polymorphism is especially likely when the effective sizes of diverging species are large and substitution rates are low $[1,46]$. Hybridization and introgression require incomplete reproductive isolation, and are obviously more likely when species grow together in a given (or in spatially close) geographic site(s). Our objectives were: i) to assess whether $A$. montana and A. laubenfelsii are genetically differentiated, and whether it is justified to treat them as two distinct species based on such data; ii) more broadly, to estimate the extent of among-species genetic variation and give some insight into their relationships; iii) to search for possible signs of introgression between species; iv) at the within-species level, to examine the spatial structure of genetic variability in order to infer the history of populations and major processes influencing their evolution (e.g. location of potential refugia and relative influence of gene flow $v s$. genetic drift).

We surveyed genetic variation on an extensive population sampling, using both nuclear (nDNA) microsatellite loci and chloroplast DNA (cpDNA) sequencing. Whereas the nuclear genome is diploid and biparentally inherited, the chloroplast genome is effectively haploid and uniparentally, paternally inherited in gymnosperms. Therefore, both genomes are dispersed through seeds and pollen but the chloroplast genome has a smaller effective population size, which makes it more sensitive to genetic drift and population/species differentiation [47]. Moreover, cpDNA is characterized by a lower mutation rate than nDNA, especially when comparing cpDNA intergenic regions to nDNA microsatellites that are highly variable markers.

\section{Methods}

Plant material

Plant material was collected from 1999 to 2008 (see Additional file 1, Figure 1). Within each site, herbarium specimens were collected for taxonomic identification based on morphological characters (following [38]), together with 2 to 48 silica-dried leaf samples (mean \pm S.D.: $21.7 \pm 8.4$ ). Sampling sites covered the entire range of species and included the vast majority of existing populations for A. montana, A. laubenfelsii, A. biramulata and A. scopulorum. Araucaria montana was sampled both on non-ultramafic (in Mt Panie and TonNon) and ultramafic soil substrates (in all other sites). The natural distribution of $A$. scopulorum is characterized by a disjunction between northwestern and eastern populations. In contrast, some (unsampled) A. rulei populations occur between the northernmost and more southern localities surveyed.

In two cases, the taxonomic identification was uncertain: i) in Pandop, close inspection of (very partial) herbarium vouchers identified the species as $A$. biramulata in almost all cases (that is, 18 samples), whereas five samples were identified as A. montana; ii) in Mt Tonta, trees were identified and considered here as $A$. biramulata but they appeared morphologically somewhat intermediate between $A$. biramulata and $A$. rulei, although the ecological characteristics were more typical of $A$. biramulata.

In total, we studied 711 samples from 32 populations and five species for nDNA (Table 1). For cpDNA, we added a few samples of $A$. muelleri and $A$. humboldtensis, as well as of $A$. columnaris and $A$. nemorosa that belong to the third Araucaria clade ([34]; Table 1). In total, the cpDNA dataset included 617 individuals from 45 populations and nine species.

\section{Nuclear microsatellites}

DNA was extracted using the DNeasy 96 Plant Kit (QIAGEN, Courtaboeuf, France). Seven nuclear microsatellite markers 


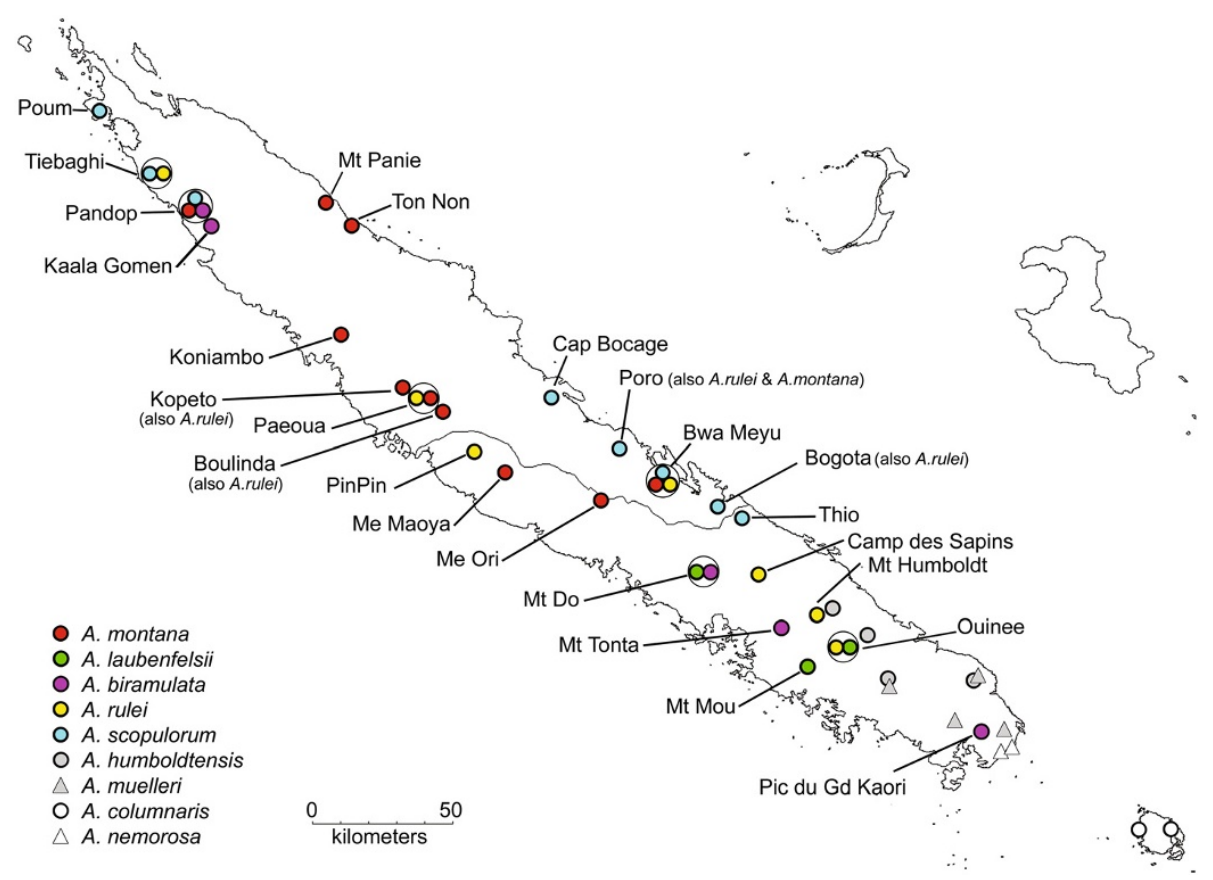

Figure 1 Map of the study populations. Dot colours follow the taxonomic identification of populations based on morphology. Sites where several species were studied are circled. Sites where several species co-occur but only one was studied are also identified, and the name of the unstudied species is mentioned.

were tentatively amplified $[28,48]$ but two of them (As110 and As152) could not be amplified or gave ambiguous profiles, and were discarded. Also, locus Aru1 failed to amplify in A. scopulorum. With the exception of Aru1, which was designed for $A$. rulei, all microsatellites were isolated and developed for $A$. subulata, a species belonging to the same cluster as A. scopulorum according to a previous AFLP phylogeny [34]. PCRs were performed in $16 \mu \mathrm{l}$ containing $1 \mu \mathrm{l}$ DNA, $1 \mathrm{X}$ Taq Buffer, $2.5 \mathrm{mM} \mathrm{MgCl}_{2}$, $0.2 \mathrm{mM}$ of each dNTP, $0.2 \mu \mathrm{M}$ of each primer (one primer per pair was fluorescently labelled), and $0.5 \mathrm{U}$ Taq polymerase (for all loci except Aru1: Taq CORE kit, MP Biomedicals, Illkirch, France; for Aru1: AmpliTaq Gold DNA polymerase, Applied Biosystems, Courtaboeuf, France). The reaction profile was: 40 cycles of $30 \mathrm{~s}$ denaturation at $95^{\circ} \mathrm{C}, 30 \mathrm{~s}$ annealing and $1 \mathrm{~min}$ elongation at $72^{\circ} \mathrm{C}$, followed by a final elongation step of $10 \mathrm{~min}$ at $72^{\circ} \mathrm{C}$. Annealing temperature was $50^{\circ} \mathrm{C}$ for As 167 and $\mathrm{As} 190$, and $52^{\circ} \mathrm{C}$ for As25 and As93. For Aru1, annealing was initiated at $62^{\circ} \mathrm{C}$, reduced by $1^{\circ} \mathrm{C}$ for the next 10 cycles, and maintained at $52^{\circ} \mathrm{C}$ for the subsequent 29 cycles. PCR products were then mixed in a $2 / 3 / 6 / 6 / 5$ ratio for As167/As190/As25/As93/Aru1, respectively and loaded on an automated sequencer (Genoscreen, Lille, France). Microsatellite profiles were manually genotyped using GeneScan 3.7 and Genotyper 3.7. For all five loci, reproducibility was checked by performing the amplification and genotyping steps twice on 38 samples. The error rate was calculated as the proportion of mismatches between duplicated, single-locus genotypes.

\section{cpDNA sequencing}

Three regions were sequenced: a subregion of the intergenic spacer $p s b \mathrm{~A}-t r n \mathrm{H}$, a subregion of the intergenic spacer $t r n S-t r n f M$ and the intergenic spacer atpH-atpI (Table 2). PCRs were carried in $25 \mu \mathrm{l}$ containing $1 \mu \mathrm{l}$ DNA template, $1 \mathrm{X}$ Taq Buffer, $2.5 \mathrm{mM} \mathrm{MgCl}, 0.2 \mathrm{mM}$ of each dNTP, $0.2 \mu \mathrm{M}$ of each primer (except for atpHatpI: $0.4 \mu \mathrm{M}$ ), and $0.5 \mathrm{U}$ Taq polymerase (Taq CORE kit). The reaction profile was: 40 cycles of $30 \mathrm{~s}$ denaturation at $95^{\circ} \mathrm{C}, 30 \mathrm{~s}$ annealing at $50^{\circ} \mathrm{C}$ (except for atp $\mathrm{H}-$ atpI: $45^{\circ} \mathrm{C}$ ) and elongation at $72^{\circ} \mathrm{C}$, followed by a final elongation step of $10 \mathrm{~min}$ at $72^{\circ} \mathrm{C}$. Elongation time was $30 \mathrm{~s}$ for $p s b \mathrm{~A}-\operatorname{trn} \mathrm{H}, 2 \mathrm{~min} 30 \mathrm{~s}$ for $\operatorname{trnS}-\operatorname{trnfM}$ and 2 min for $a t p \mathrm{H}-a t p \mathrm{I}$. PCR products were then sequenced in both directions at the Centre National de Séquençage (Evry, France). The resulting sequences were manually inspected in Sequencher ${ }^{\circ} 4.9$ (Gene Codes Corporation, Ann Arbor, MI, USA), and aligned in MEGA 4.0.1 [49]. Since cpDNA does not experience recombination, we concatenated the sequences of the three genomic regions, so that each sample was characterized by its multi-region haplotype. In order to include both substitutions and microsatellites (mononucleotide repeats) in our analyses, and because computer programs sometimes exclude gaps in calculations, we coded microsatellites as A when a 


\begin{tabular}{|c|c|c|c|c|c|c|c|c|c|c|}
\hline $\begin{array}{l}\text { Species or } \\
\text { population }\end{array}$ & $\begin{array}{l}\text { Number of } \\
\text { samples } \\
\text { studied } \\
\text { for nDNA }\end{array}$ & $H_{\mathrm{E}}$ & $\begin{array}{l}A R \text { (based } \\
\text { on a minimal } \\
\text { size of } 3 \text { indiv.) }\end{array}$ & $F_{\text {IS }}$ & $\begin{array}{l}\text { Mean pairwise } F_{\mathrm{ST}} \\
\& \text { species-level } F_{\mathrm{ST}} \\
\text { (with/without } \\
\text { locus Aru1) }\end{array}$ & $\begin{array}{l}\text { Number of } \\
\text { samples studied } \\
\text { for cpDNA }\end{array}$ & $\begin{array}{l}\text { Number of } \\
\text { cpDNA } \\
\text { haplotypes }\end{array}$ & $\begin{array}{l}H R \text { (based on } \\
\text { a minimal size } \\
\text { of } 6 \text { indiv.) }\end{array}$ & MNbPwDiff & $\begin{array}{l}\text { Mean pairwise } N_{\mathrm{ST}} \\
\text { \& species-level } N_{\mathrm{ST}}\end{array}$ \\
\hline $\begin{array}{l}\text { A. montana- } \\
\text { A. laubenfelsii }\end{array}$ & 274 & $0.793 \pm 0.126$ & $3.98 \pm 0.73$ & $0.116 \pm 0.082$ & $0.105 / 0.109$ & 213 & 28 (26 specific) & $4.04 \pm 1.48^{\mathrm{ab}}$ & $1.152 \pm 0.487^{\mathrm{a}}$ & 0.203 \\
\hline TonNon & 24 & 0.516 & 2.33 & 0.190 & $0.246 \pm 0.036$ & 23 & 1 & 1.00 & 0.000 & $0.318 \pm 0.139$ \\
\hline Mt Panie & 10 & 0.540 & 2.66 & 0.081 & $0.222 \pm 0.044$ & 10 & 3 & 2.85 & 1.133 & $0.263 \pm 0.092$ \\
\hline Pandop & 2 & - & - & - & - & 2 & 1 & - & - & - \\
\hline Koniambo & 48 & 0.842 & 4.13 & $0.206^{*}$ & $0.114 \pm 0.058$ & 32 & 6 & 4.11 & 1.462 & $0.283 \pm 0.061$ \\
\hline Kopeto & 6 & 0.840 & 4.40 & 0.206 & $0.094 \pm 0.095$ & 6 & 3 & 3.00 & 0.933 & $0.175 \pm 0.156$ \\
\hline Paeoua & 26 & 0.860 & 4.40 & $0.194^{*}$ & $0.085 \pm 0.064$ & 16 & 6 & 5.04 & 1.775 & $0.092 \pm 0.095$ \\
\hline Boulinda & 10 & 0.827 & 4.02 & -0.023 & $0.129 \pm 0.080$ & 10 & 3 & 2.85 & 0.933 & $0.170 \pm 0.155$ \\
\hline Me Maoya & 24 & 0.902 & 4.73 & $0.132^{*}$ & $0.077 \pm 0.069$ & 16 & 8 & 6.24 & 1.817 & $0.102 \pm 0.101$ \\
\hline Me Ori & 24 & 0.859 & 4.41 & 0.015 & $0.082 \pm 0.072$ & 15 & 7 & 5.47 & 1.524 & $0.130 \pm 0.122$ \\
\hline Bwa Meyu & 26 & 0.826 & 4.13 & 0.079 & $0.082 \pm 0.063$ & 20 & 4 & 3.55 & 0.884 & $0.131 \pm 0.093$ \\
\hline Mt Do & 25 & 0.840 & 4.28 & 0.082 & $0.079 \pm 0.069$ & 25 & 6 & 3.94 & 0.947 & $0.162 \pm 0.121$ \\
\hline Mt Mou & 25 & 0.816 & 4.08 & 0.030 & $0.091 \pm 0.071$ & 22 & 8 & 5.50 & 1.234 & $0.306 \pm 0.164$ \\
\hline Ouinee & 24 & 0.849 & 4.25 & $0.194^{*}$ & $0.075 \pm 0.068$ & 16 & 7 & 4.95 & 1.183 & $0.240 \pm 0.162$ \\
\hline A. biramulata & 86 & $0.750 \pm 0.092$ & $3.58 \pm 0.56$ & $0.107 \pm 0.059$ & $0.151 / 0.156$ & 87 & 8 (4 specific) & $2.79 \pm 0.72^{\mathrm{a}}$ & $1.032 \pm 0.981^{\mathrm{ab}}$ & 0.433 \\
\hline Pandop & 21 & 0.812 & 3.99 & $0.136^{*}$ & $0.126 \pm 0.094$ & 21 & 2 & 1.76 & 0.181 & $0.211 \pm 0.311$ \\
\hline Kaala Gomen & 24 & 0.828 & 4.04 & 0.058 & $0.130 \pm 0.099$ & 23 & 4 & 3.03 & 0.704 & $0.176 \pm 0.280$ \\
\hline Mt Do & 19 & 0.735 & 3.47 & 0.176 & $0.168 \pm 0.033$ & 19 & 5 & 3.41 & 0.795 & $0.170 \pm 0.258$ \\
\hline Mt Tonta & 22 & 0.626 & 2.83 & 0.059 & $0.211 \pm 0.008$ & 22 & 3 & 2.95 & 2.446 & $0.512 \pm 0.052$ \\
\hline Pic du Grand Kaori & 0 & - & - & - & - & 2 & 1 & - & - & - \\
\hline A. rulei & 155 & $0.805 \pm 0.035$ & $4.00 \pm 0.20$ & $0.074 \pm 0.047$ & $0.105 / 0.119$ & 107 & 13 (10 specific) & $3.07 \pm 1.22^{\mathrm{a}}$ & $1.143 \pm 0.619^{\mathrm{ab}}$ & 0.108 \\
\hline Tiebaghi & 24 & 0.832 & 4.12 & 0.015 & $0.100 \pm 0.017$ & 16 & 1 & 1.00 & 0.000 & $0.220 \pm 0.166$ \\
\hline Paeoua & 20 & 0.825 & 4.11 & 0.084 & $0.132 \pm 0.026$ & 13 & 3 & 2.72 & 1.359 & $0.090 \pm 0.124$ \\
\hline Pin Pin & 20 & 0.823 & 4.12 & 0.032 & $0.117 \pm 0.017$ & 15 & 4 & 3.59 & 1.657 & $0.056 \pm 0.072$ \\
\hline Bwa Meyu & 24 & 0.784 & 3.88 & $0.131^{*}$ & $0.093 \pm 0.026$ & 16 & 6 & 4.67 & 1.592 & $0.197 \pm 0.181$ \\
\hline CDS & 23 & 0.847 & 4.25 & 0.047 & $0.085 \pm 0.018$ & 15 & 5 & 4.07 & 1.200 & $0.056 \pm 0.078$ \\
\hline Mt Humboldt & 20 & 0.765 & 3.78 & 0.075 & $0.104 \pm 0.034$ & 16 & 3 & 2.23 & 0.608 & $0.096 \pm 0.121$ \\
\hline Ouinee & 24 & 0.759 & 3.71 & 0.137 & $0.109 \pm 0.035$ & 16 & 4 & 3.23 & 1.583 & $0.052 \pm 0.081$ \\
\hline
\end{tabular}


Table 1 Statistics on the genetic diversity and structure of the study populations based on nuclear and chloroplast datasets (Continued)

\begin{tabular}{|c|c|c|c|c|c|c|c|c|c|c|}
\hline A. scopulorum & 198 & $0.774 \pm 0.023$ & $3.67 \pm 0.18$ & $0.191 \pm 0.060$ & $-/ 0.119$ & 187 & 23 (21 specific) & $4.88 \pm 0.58^{b}$ & $1.555 \pm 0.346^{b}$ & 0.293 \\
\hline Poum & 24 & 0.757 & 3.40 & $0.277^{*}$ & $0.157 \pm 0.050$ & 22 & 7 & 4.63 & 1.307 & $0.317 \pm 0.203$ \\
\hline Tiebaghi & 24 & 0.762 & 3.56 & 0.207 & $0.127 \pm 0.021$ & 21 & 6 & 5.06 & 1.914 & $0.298 \pm 0.184$ \\
\hline Pandop & 23 & 0.824 & 4.01 & 0.129 & $0.106 \pm 0.026$ & 22 & 7 & 4.37 & 1.619 & $0.295 \pm 0.205$ \\
\hline Cap Bocage & 33 & 0.780 & 3.75 & $0.160^{*}$ & $0.105 \pm 0.044$ & 31 & 6 & 4.49 & 1.170 & $0.231 \pm 0.205$ \\
\hline Poro & 24 & 0.773 & 3.59 & 0.197 & $0.098 \pm 0.058$ & 23 & 7 & 5.51 & 1.447 & $0.203 \pm 0.210$ \\
\hline Bwa Meyu & 24 & 0.766 & 3.76 & 0.146 & $0.098 \pm 0.050$ & 24 & 6 & 4.16 & 1.112 & $0.281 \pm 0.219$ \\
\hline Bogota & 24 & 0.749 & 3.61 & 0.134 & $0.137 \pm 0.042$ & 23 & 6 & 5.00 & 1.937 & $0.206 \pm 0.120$ \\
\hline Thio & 22 & 0.777 & 3.68 & $0.279^{*}$ & $0.086 \pm 0.038$ & 21 & 8 & 5.85 & 1.933 & $0.185 \pm 0.177$ \\
\hline A. humboldtensis & 0 & - & - & - & - & 8 & 2 & - & - & - \\
\hline A. muelleri & 0 & - & - & - & - & 7 & 3 & - & - & - \\
\hline A. columnaris & 0 & - & - & - & - & 4 & 2 & - & - & - \\
\hline A. nemorosa & 0 & - & - & - & - & 4 & 2 & - & - & - \\
\hline TOTAL & 713 & - & 145 alleles & - & Overall: 0.143 & 617 & 71 & - & - & Overall: 0.646 \\
\hline
\end{tabular}

For each species, populations are ordered from North to South below the species-level estimates. $H_{\mathrm{E}}$ : expected heterozygosity; $A R$ : allelic richness; $H R$ : haplotypic richness; $M N b P w D i f f$ mean number of pairwise differences between pairs of individuals. *indicates $F_{I S}$ indices that were significantly $>0$. All nDNA estimates include locus Aru1, except for $A$. scopulorum populations. CpDNA haplotypes are characterized as 'specific' to a species when they only occur in this species. Different letters as superscripts after species means indicate significantly different values. 
Table 2 Primers used for cpDNA PCR and sequencing

\begin{tabular}{llll}
\hline Genomic region & Primer name & Primer sequence & Reference \\
\hline partial psbA-trnH & HAm_F & CCGATGGATTGTTAGTGTGT & - \\
partial psbA-trnH & HAm_R & TTCTATGATTAGAAGAGTCC & - \\
partial trnS-trnfM & trnS & GAGAGAGAGGGATTCGAACC & - \\
partial trnS-trnfM & AP3R & CCCTGGCAAAGAGAATTTACC & - \\
partial trnS-trnfM & AP1F* & TCCCTCTTCTCTCCCACTCAAAT & [51] \\
aptH-atpl & atpH & CCAGCAGCAATAACGGAAGC & [51] \\
apt $\mathrm{H}-$ atpl & atpl & ATAGGTGAATCCATGGAGGG & \\
\hline
\end{tabular}

*only used for sequencing.

repeat was present and $\mathrm{T}$ when it was absent (i.e. in place of gaps).

\section{Statistical analyses}

Nuclear and chloroplast datasets were analyzed separately. For each dataset, some analyses were performed on the total sampling i.e. simultaneously considering all species, while others were computed within each species separately. For nDNA, among-species comparisons including A. scopulorum were run on a dataset excluding locus Aru1 so that the data were comparable.

Based on the results obtained on the multispecies dataset, A. montana and A. laubenfelsii were considered as a single species in the within-species analyses. The $A$. montana samples from Pandop and $A$. biramulata samples from Pic du Grand Kaori were removed from analyses at the population level because sample sizes were too low (see Results for A. montana in Pandop). Last, we did not consider the geographic structure of genetic diversity in $A$. biramulata, because our sampling was too limited and two populations seemed to undergo genetic exchange with other species (see below), precluding reliable within-species inferences.

\section{Nuclear microsatellites}

Multispecies analyses to examine species divergence and relationships We used Structure version 2.3.3 [52,53] to cluster individual genotypes into $K$ genetically distinct clusters. Structure was run ten times for each $K$-value from one to eight to check the consistency of the results across runs. Each run comprised a burn-in of 200000 iterations followed by $10^{6}$ iterations. We adopted the admixture and correlated allele frequencies models. We used StructureHarvester v0.6.93 [54] to plot the relationship between $K$ and (i) the probability of the data $\mathrm{L}(K)$ and (ii) the ad hoc statistic $\Delta K$ recommended by Evanno et al. [55]. We identified the most relevant number of clusters as the one that maximized $\mathrm{L}(K)$ and/or $\Delta K$. A similar analysis was run with a reduced dataset, only including A. montana and A. laubenfelsii populations.
Based on the matrix of $F_{\mathrm{ST}}$ indices between all pairs of populations (see below), the relationships between populations were visualized using the network-building distance-based algorithm Neighbor-Net [56,57] implemented in Splistree4 [58].

The overall population differentiation was quantified by the estimator $\theta$ of $F_{\mathrm{ST}}$ [59], calculated in FSTAT [60], and hierarchical analyses of molecular variance (AMOVAs) were conducted to partition the total genetic variance into among-species, among-population within species, and among-individual within population components using Arlequin [61]. Analyses were performed considering the whole dataset, and datasets reduced to pairs of species.

Within-species analyses to explore the spatial structuring of genetic diversity Within all populations, genetic diversity was estimated as allelic richness ( $A R$; mean number of alleles per locus based on the minimal sample size; [62]) and expected heterozygosity $\left(H_{\mathrm{E}}\right)$ using FSTAT. The correlation between population diversity $\left(A R, H_{\mathrm{E}}\right)$ and latitude was tested through non-parametric Spearman rank correlations in Minitab 12.2 (Minitab Inc., State College, PA, USA). To detect signs of recent bottlenecks, we examined deviations in heterozygosity from mutation-drift equilibrium in each population with the software Bottleneck [63]. We assumed that microsatellite loci follow a twophase mutation model with $70 \%$ single-step mutations and 30\% multiple-step mutations.

Within each species, genetic structure was quantified by within-population $F_{\mathrm{IS}}$ and among-population $F_{\mathrm{ST}}$ indices using FSTAT, and AMOVAs were used to partition the genetic variance into among-population and amongindividual within population components. The statistical significance of $F_{\mathrm{IS}}$ was assessed by permutations of alleles in each population at each locus, followed by a Bonferroni correction for multiple tests. $F_{\mathrm{ST}}$ indices were calculated both at the species level and among all pairs of populations. The overall divergence of each population was quantified as the mean pairwise $F_{\mathrm{ST}}$ between each population and all conspecifics. Exact tests of population 
differentiation were also performed among all pairs of populations using Genepop [64] and applying a Bonferroni correction (Kopeto was excluded from these tests because of low sample size). We tested the pattern of isolation by distance by performing Mantel tests with 10000 random permutations to compare the genetic and geographic distance matrices. The matrix of geographic distances was calculated from the spatial coordinates of each population using the Geographic Distance Matrix Generator [65]. In order to examine into more details the geographic structure of the genetic diversity, we ran Structure within each species. The analysis parameters were the same as for the multispecies analysis.

Among pairs of species, differences in population $A R$, $H_{\mathrm{E}}, F_{\mathrm{IS}}$ and overall within-species $F_{\mathrm{ST}}$ were assessed using permutation tests in FSTAT.

\section{cpDNA sequencing}

Multispecies analyses We constructed both a haplotype and a population network, using the Neighbor-Net algorithm of Splitstree4 and based on the uncorrected p-distances (i.e. the number of changes between two haplotypes) and pairwise Nst indices (see below), respectively. Using Arlequin, we computed an AMOVA to estimate the proportion of the overall genetic variance found among species, among populations within species, and among individuals within population.

Within-species analyses Within all populations, genetic diversity was estimated as haplotype richness (HR; calculated in FSTAT by considering distinct haplotypes as distinct alleles of a single, always homozygous locus) and mean number of pairwise differences between pairs of individuals (MNbPwDiff; calculated in Arlequin).

Within each species, among-population differentiation was quantified by $N_{\mathrm{ST}}$ indices both at the species level and among all pairs of populations using SPAGeDi 1.4 [66]. Compared to $G_{\mathrm{ST}}$, which only considers alleles/haplotypes frequencies, $N_{\mathrm{ST}}$ also takes into account the divergence between haplotypes. Here, we used mean number of pairwise differences as a measure of haplotype divergence (similar to uncorrected p-distances and computed in Arlequin), and we performed 10000 permutations of rows and columns of the distance matrix between haplotypes to test whether $N_{\mathrm{ST}}>G_{\mathrm{ST}}$. Such a significant relationship suggests that distinct haplotypes are more related within populations than among them, and comparing $N_{\mathrm{ST}}$ and $G_{\mathrm{ST}}$ allows assessing the importance of mutation relative to other causes of genetic differentiation (gene flow and divergence time; [67]).

Among pairs of species, differences in population $H R$ was assessed using permutation tests in FSTAT, while t-tests were performed in Minitab 12.2 to check for differences in i) $M N b P w D i f f$ within populations, and ii) $N_{\mathrm{ST}}$ indices among all pairs of populations within species.

\section{Results}

The five nuclear microsatellite loci displayed 23 to 35 alleles each, leading to 145 alleles observed in total. The overall reproducibility of genotyping was $92 \%$. The concatenated, aligned cpDNA sequences were 1920 base pairs long (respectively 334, 850 and 736 bp for partial psbA-trn $\mathrm{H}$, partial trnS-trnfM and $a t p \mathrm{H}-a t p \mathrm{I})$ and comprised 25 variable sites (4, 16 and 5 respectively) among which 16 nucleotide substitutions and 9 microsatellites displaying 2 to 5 alleles each. This allowed defining 71 haplotypes, each observed in one to 78 individuals.

\section{Multispecies analyses to examine species divergence and relationships \\ Nuclear microsatellites}

In Structure, the probability of the data increased from $K=1$ to $K=8$ (Figure $2 \mathrm{~A}$ ). The method of Evanno et al. [55] suggested $K=3$ as the most adequate number of clusters. However, previous knowledge [34] and other results of this study proved that $A$. scopulorum was the most divergent species included here. Since all $A$. scopulorum populations started to form a distinct cluster, excluding populations of other species, from $K=5$, we considered the results from this $K$-value. The clustering of populations differed between $K=5$ and $K=6$ but, from $K=6$, remained consistent. In addition, $K=7$ allowed a clear increase of $\mathrm{L}(K)$. We therefore considered $K=7$ as the biologically most plausible number of clusters. The major clusters were: 1 ) the three $A$. scopulorum populations from the northwestern coast; 2) the five $A$. scopulorum populations from the eastern coast; 3 ) all $A$. rulei populations; 4) the two northeastern $A$. montana populations (Mt Panie and TonNon); 5) the Koniambo A. montana population; 6) the remaining $\operatorname{six} A$. montana populations (with the exception of Pandop and with quite strong admixture for the northernmost populations), three $A$. laubenfelsii populations and the $A$. biramulata Mt Do population; 7) the three A. biramulata populations Pandop, Kaala Gomen and Mt Tonta and two samples identified as A. montana in Pandop (which were admixed with the Koniambo A. montana cluster). At the sample level, we observed that some other individuals were admixed, with their genotype originating not only from a cluster characteristic of the species they belong to based on morphological grounds but also, to a large extent, to other clusters: some A. montana samples were admixed with the A. rulei and/ or A. scopulorum clusters in Paeoua, Boulinda and $\mathrm{Me}$ Maoya; some $A$. scopulorum samples were largely assigned to the A. biramulata cluster in Bogota; and a few A. biramulata and $A$. rulei samples were largely assigned to an A. scopulorum cluster in various sites (Figure 2A). 


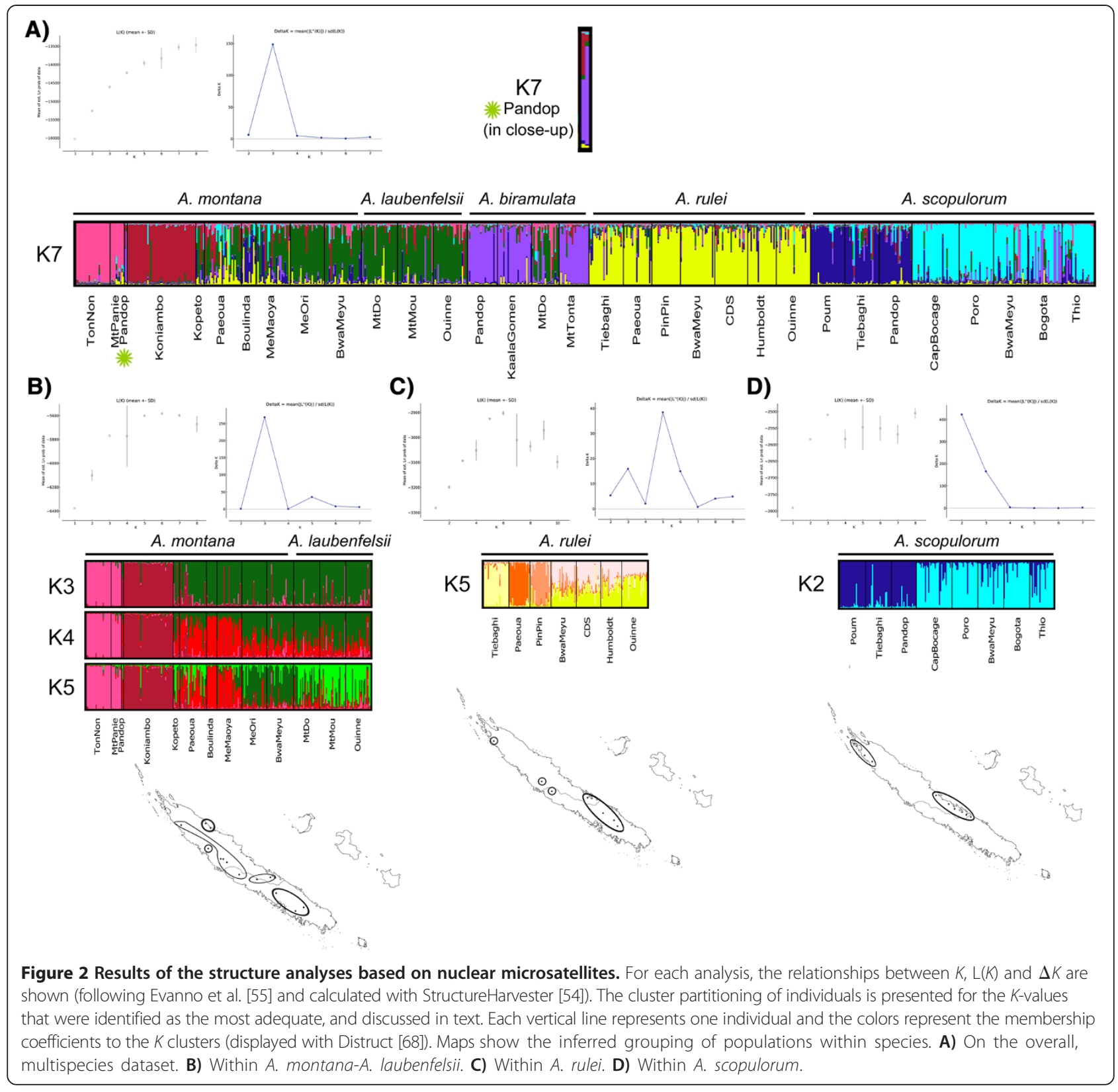

When the analysis was restricted to A. montana and $A$. laubenfelsii, the Mt Panie and TonNon populations on the one hand, and Koniambo population on the other hand were again found to be clearly differentiated from all others (Figure $2 \mathrm{~B}, \mathrm{~K}=3$ ). Among the nine remaining populations (excluding Pandop, which was more related to A. biramulata based on the previous analysis and not discussed here), two genetic clusters formed a rough genetic cline from north (Kopeto) to south (Ouinee) at $\mathrm{K}=4$ and, at $\mathrm{K}=5$, three clusters were retrieved that broadly consisted of the $A$. montana Kopeto-Paeoua-Boulinda-Me Maoya populations, A. montana Me Ori-Bwa Meyu populations, and A. laubenfelsii Mt Do-Mt Mou-Ouinee populations (Figure 2B).
The nDNA population network showed the same patterns: short branches suggested strong genetic relatedness among species but $A$. scopulorum, A. rulei, A. biramulata and A. montana-A. laubenfelsii formed clearly separate groups (Figure 3). However, there were some exceptions. In particular, the $A$. biramulata Mt Do population was retrieved in the A. montana-A. laubenfelsii group (in agreement with Structure) and the $A$. biramulata Mt Tonta population appeared in an intermediate position between A. montana-A. laubenfelsii and A. scopulorum. As in the Structure analysis, we also observed the eastern vs. northwestern differentiation in A. scopulorum, and the strong divergence of the Panie, TonNon and to a lesser extent 


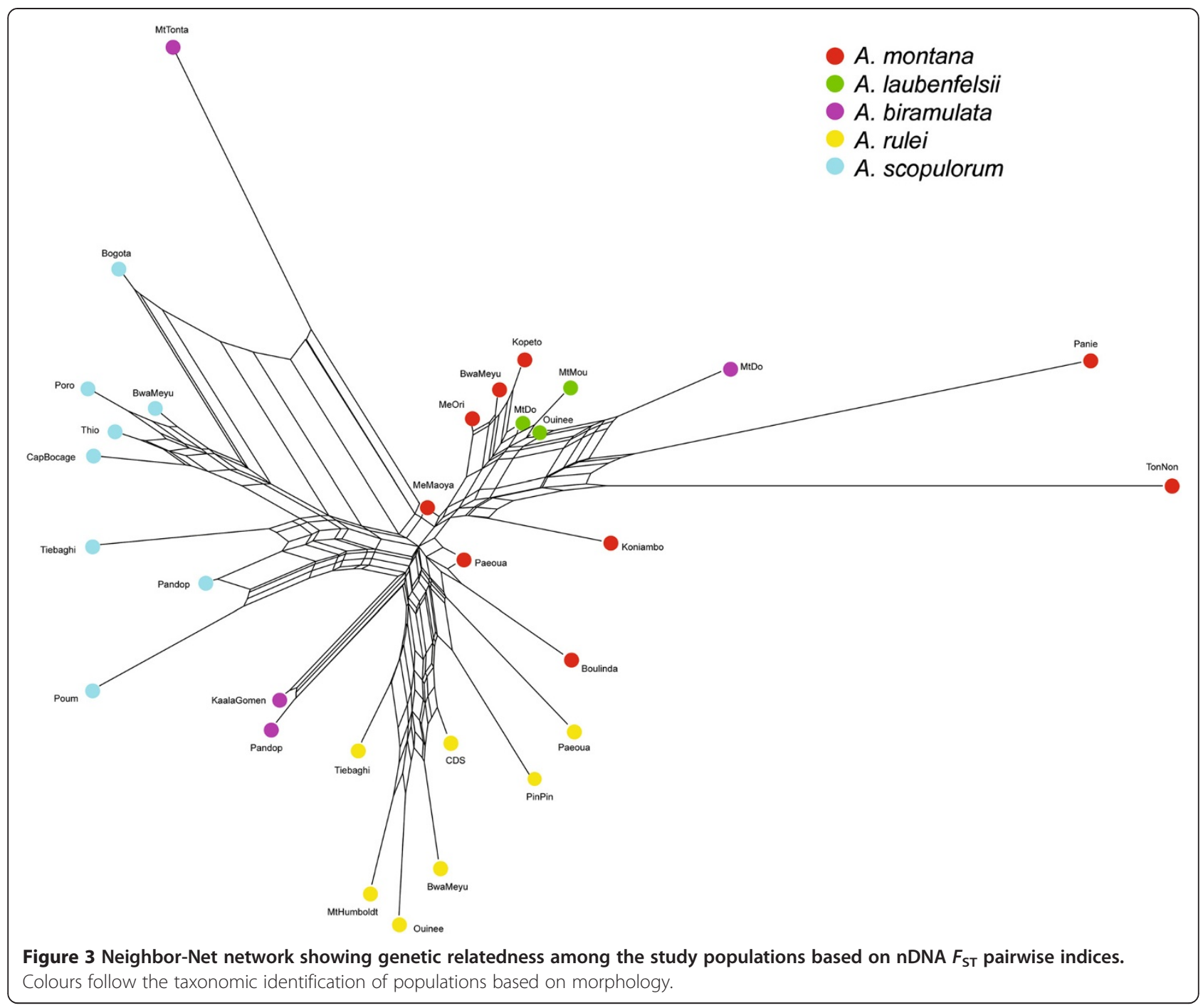

Koniambo populations compared to other A. montana-A. laubenfelsii populations. The $A$. montana Paeoua and Boulinda populations appeared genetically close to the $A$. rulei Paeoua and PinPin populations, in an intermediate position between the two species.
The overall multispecies nDNA $F_{\mathrm{ST}}$ was 0.143 . The AMOVA showed a low proportion of the genetic variance among species (5.2\%), most of it being observed among populations within species (11.5\%) and within populations $(83.3 \%)$. When restricting the analysis to

Table 3 Results of the AMOVA analyses based on nuclear and chloroplast datasets

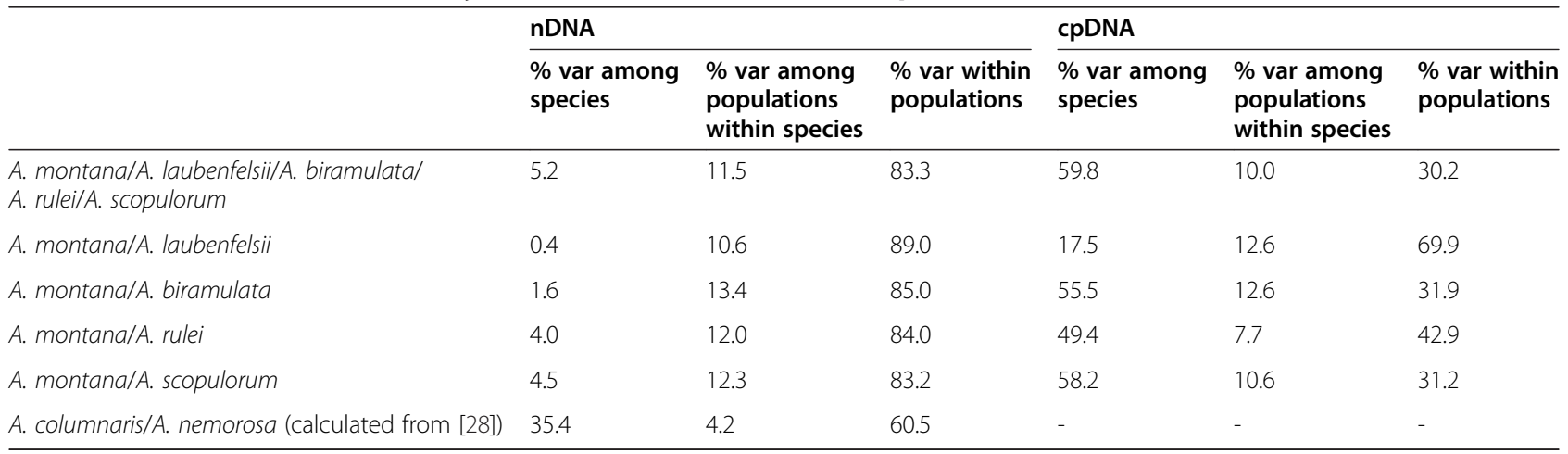


A. montana and A. laubenfelsii, only $0.4 \%$ of the variance was observed between species, which was a much lower proportion than between A. montana and other species (Table 3).

\section{Chloroplast DNA sequencing}

Most cpDNA haplotypes occurred in only one species (Figure 4) and will be referred as 'specific' to this species. The remaining 14 haplotypes were shared by several species, and A. montana and A. laubenfelsii shared as many as five haplotypes while other pairs of species only shared at most one.

In the haplotype network, most haplotypes clustered according to taxonomy (Figure 4). In particular, some samples were retrieved with their conspecifics although the Structure analysis based on nDNA grouped them with another species. It was the case in Mt Do, where all A. biramulata samples (except Mt Do_4090) displayed cpDNA haplotypes specific to A. biramulata (H05 to H08) although they clustered with $A$. montana and A. laubenfelsii based on nDNA (Table 4). In contrast, some individuals that were morphologically and, based on $\mathrm{nDNA}$, assigned to a given species displayed haplotypes that were shared with (or closer to haplotypes observed in) other species (Table 4). All haplotypes of these outlying samples were checked by repeating the PCR reactions. Most importantly, twelve (out of 22) samples of $A$. biramulata from $\mathrm{Mt}$ Tonta shared a haplotype that was otherwise only found in A. rulei (H65). In contrast, these samples clearly clustered with $A$. biramulata based on nDNA. Also, out of the five samples from Pandop and identified as A. montana, we observed that three harboured a cpDNA haplotype specific to $A$. biramulata (H07) whereas two displayed a cpDNA haplotype specific to $A$. montana (H58). All clustered with the $A$. biramulata nDNA cluster. Morphological identification was uncertain and we therefore revised it and considered the three samples with both nDNA and cpDNA related to $A$. biramulata as $A$. biramulata samples in population analyses. The two individuals with cpDNA haplotypes specific to $A$. montana were excluded from population analyses because of the low sample size in this site $(n=2)$. Other cases of cpDNA vs. nDNA incongruence are summarized in Table 4.

In the population network based on cpDNA data, the distinction among species was clear and even more pronounced than based on nDNA (Figure 5). As with nDNA markers, this was however not true for $A$. montana and $A$. laubenfelsii, whose populations were grouped although the $A$. laubenfelsii populations appeared at the extremity of the A. montana-A. laubenfelsii portion of the network. Also, the $A$. biramulata Mt Tonta population was retrieved with $A$. rulei, which was expected given haplotype sharing. Similarly to what was found for nDNA, A. scopulorum populations separated into two geographic groups.
The overall cpDNA differentiation index $N_{\mathrm{ST}}$ was 0.646 . Consistent with the clear discrimination of species on the population network, the AMOVA showed that $59.8 \%$ of the variation was found among species, $10.0 \%$ within species among populations, and $30.2 \%$ within populations. When considering pairs of species, the among-species component of the variance represented $17.5 \%$ of the total variance between $A$. montana and A. laubenfelsii, which was much lower than between other pairs of species (most often about $50 \%$; Table 3 ).

Within-species analyses to explore the spatial structuring of genetic diversity

Differences among species in the levels of genetic diversity and structure

At nuclear loci, there was no significant difference in within-population diversity among species (Table 1), and no population showed signs of a recent bottleneck. For cpDNA, A. scopulorum showed the highest levels of population diversity (Table 1 ). It also displayed larger withinpopulation $F_{\mathrm{IS}}$ indices than all other species: the mean $F_{\mathrm{IS}}$ was 0.191 while other species had mean $F_{\mathrm{IS}}<0.080$ when excluding locus Aru1 ( $P=0.002$ among all species; significant between all pairs of species involving A. scopulorum; Table 1).

There was no significant difference across species in population differentiation at nuclear loci, with $F_{\mathrm{ST}}$ ranging from 0.109 and 0.156 (Table 1). AMOVAs also showed similar proportions of the variance among populations across species: $10.1 \%$ in $A$. montana- $A$. laubenfelsii and A. rulei, $10.4 \%$ in $A$. scopulorum and $12.1 \%$ in $A$. biramulata. For cpDNA, species-level Nst estimates ranged from 0.108 in $A$. rulei to 0.433 in A. biramulata (Table 1). This high value in $A$. biramulata was probably explained by the specific $A$. rulei haplotype exhibited by one part of the Mt Tonta population. Araucaria montana-A. laubenfelsii and $A$. scopulorum showed intermediate values and, based on Nst estimates among all pairs of populations, displayed significantly stronger differentiation than $A$. rulei ( $P=0.014$ and $P=0.003$, respectively). The amongpopulation differentiation index Nst was statistically higher than Gst in A. biramulata $\left(G_{\mathrm{ST}}=0.269, P=0.007\right.$; but only based on four populations and with a probably strong bias due to Mt Tonta, see above) and in A. scopulorum $\left(G_{\mathrm{ST}}=0.174, P=0.001\right)$. The relationship was however not significant anymore when we restricted the analysis to the northwestern and eastern parts of the $A$. scopulorum distribution area, respectively. In $A$. montanaA. laubenfelsii and A. rulei, $G_{\mathrm{ST}}$ estimates were 0.185 and 0.144 .

Spatial structure of the genetic differentiation within species In A. montana-A. laubenfelsii (12 populations) CpDNA haplotypic richness was significantly correlated with 


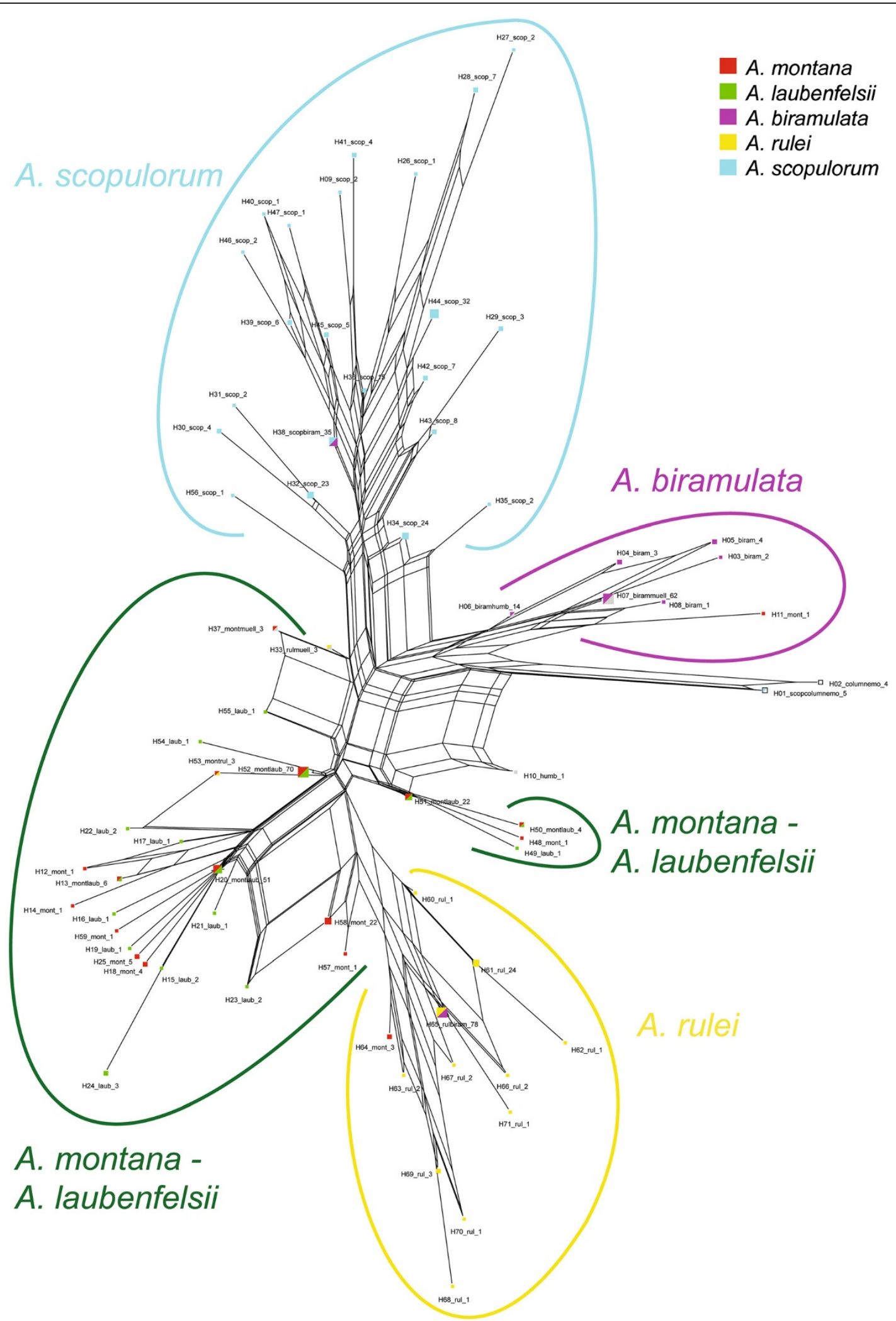

Figure 4 Neighbor-Net network showing genetic relatedness among the observed cpDNA haplotypes based on uncorrected p-distances. Each haplotype is designated with its number ( $\mathrm{HO1}$ to H71), followed by the name(s) of the species and number of samples displaying the haplotype. Colours follow the taxonomic identification of populations based on morphology. 
Table 4 Incongruent patterns observed between nDNA and cpDNA

\begin{tabular}{|c|c|c|c|c|c|c|}
\hline Population & $\begin{array}{l}\text { Morphology-based } \\
\text { species identification }\end{array}$ & $\begin{array}{l}\text { Number of } \\
\text { samples } \\
\text { studied for } \\
\text { cpDNA }\end{array}$ & $\begin{array}{l}\text { Number of } \\
\text { samples } \\
\text { involved in the } \\
\text { incongruence }\end{array}$ & cpDNA haplotype specific to: & nDNA characteristic of*: & $\begin{array}{l}\text { Hypothesized evolutionary } \\
\text { scenario (see text) }\end{array}$ \\
\hline Mt Do & A. biramulata & 19 & 18 & A. biramulata ( $\mathrm{H} 05$ to $\mathrm{H} 08$ ) & A. montana-A. laubenfelsii & Introgression \\
\hline Mt Tonta & A. biramulata & 22 & 12 & A. rulei $(\mathrm{H} 65)$ & A. biramulata & $\begin{array}{l}\text { Introgression (or shared ancestral } \\
\text { polymorphism) }\end{array}$ \\
\hline \multirow[t]{2}{*}{ Pandop } & A. montana & 5 & 3 & A. biramulata $(\mathrm{H} 07)$ & A. biramulata & $\begin{array}{l}\text { Erroneous species identification, } \\
\text { which was revised to A. biramulata for } \\
\text { population analyses }\end{array}$ \\
\hline & & & 2 & A. montana $(\mathrm{H} 58)$ & A. biramulata & Introgression \\
\hline Paeoua & A. rulei & 13 & 1 & $\begin{array}{l}\text { A. muelleri }(\mathrm{H} 33) \text {; closer to A.montana-A. laubenfelsii } \\
\text { haplotypes than to A. rulei ones }\end{array}$ & A. rulei & Introgression \\
\hline Ouinee & A. rulei & 16 & 1 & $\begin{array}{l}\text { A. muelleri (H33); closer to A.montana-A. laubenfelsii } \\
\text { haplotypes than to A. rulei ones }\end{array}$ & A. rulei & Introgression \\
\hline PinPin & A. rulei & 15 & 1 & $\begin{array}{l}\text { A. montana ( } \mathrm{H} 53) \text {; but close }(\mathrm{d}=1 \text { change) to the } \\
\text { abundant } A \text {. rulei haplotype } \mathrm{H} 61\end{array}$ & A. rulei & Population-specific cpDNA haplotype \\
\hline Panie & A. montana & 10 & 3 & $\begin{array}{l}\text { H64, retrieved with A. rulei haplotypes but close } \\
(\mathrm{d}=2 \text { changes) to the common A. montana- } \\
\text { A. laubenfelsii haplotype } \mathrm{H} 52\end{array}$ & A. montana-A. laubenfelsii & Shared ancestral polymorphism \\
\hline Paeoua & A. montana & 16 & 1 & $\mathrm{H} 11$, retrieved with $A$. biramulata haplotypes & $\begin{array}{l}\text { More related to } \text { A. montana- } \\
\text { A. laubenfelsii than to } \\
\text { A. biramulata }\end{array}$ & Shared ancestral polymorphism \\
\hline Mt Do & A. biramulata & 19 & 1 & A. scopulorum (H38) & A. montana-A. laubenfelsii & $\begin{array}{l}\text { Shared ancestral polymorphism } \\
\text { (at cpDNA) and introgression with } \\
\text { A. montana-A. laubenfelsii }\end{array}$ \\
\hline Thio & A. scopulorum & 21 & 1 & A. columnaris and A. nemorosa ( $\mathrm{H} 01)$ & A. scopulorum & $\begin{array}{l}\text { Insufficient data to propose an } \\
\text { evolutionary scenario }\end{array}$ \\
\hline
\end{tabular}

In bold: the species identification upon which two datasets agree (out of the three datasets: morphology, cpDNA and nDNA).

*A sample was considered as characteristic of a given species when $>50 \%$ of its genotype was assigned to the genetic cluster(s) of this species. 


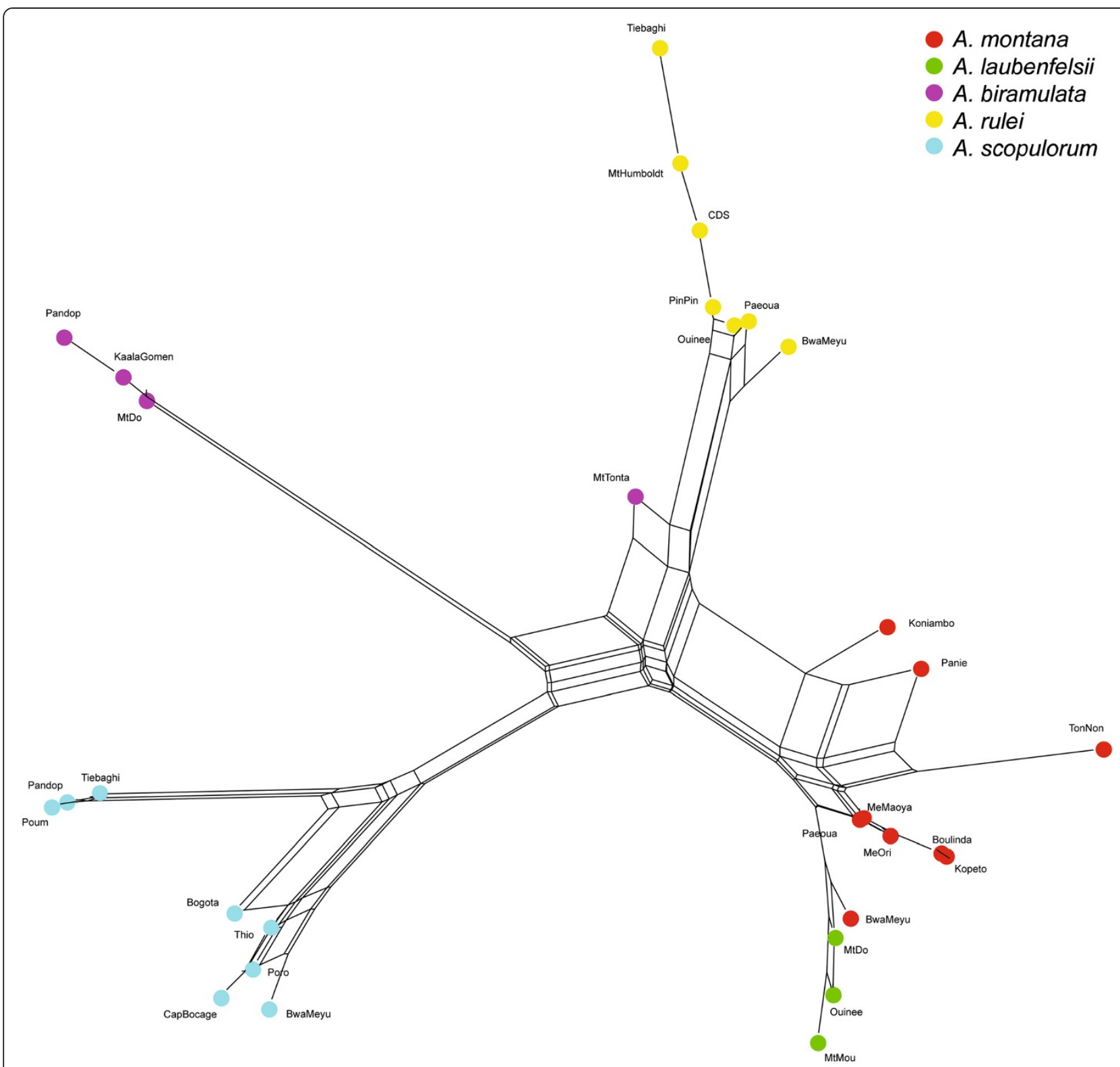

Figure 5 Neighbor-Net network showing genetic relatedness among the study populations based on cpDNA $N_{\text {ST }}$ pairwise indices. Colours follow the taxonomic identification of populations based on morphology.

latitude $(P=0.026 ; r=-0.64)$, with the northernmost populations Mt Panie and TonNon displaying very low diversity and central/southern populations harbouring relatively high numbers of (often private) haplotypes (Table 1). No such geographic trend was observed for other cpDNA or nDNA diversity estimates. At nDNA loci, we detected significant deficits of heterozygotes in Koniambo, Paeoua, Me Maoya and Ouinee $\left(F_{\mathrm{IS}}=0.132\right.$ to 0.206; Table 1). The Structure analysis based on nDNA suggested the existence of five genetic clusters, which were highly congruent with geography although the Mantel test was not significant (Figure 2B). Two clusters were strongly differentiated and composed of the northern populations Mt Panie-TonNon and Koniambo. Although they belonged to the same cluster, Mt Panie and TonNon were also strongly divergent: they displayed the highest pairwise $F_{\mathrm{ST}}$ estimate within $A$. montana-A. laubenfelsii $\left(F_{\mathrm{ST}}=0.315\right)$ and split in two distinct clusters at $K=6$. Other genetic clusters were less clear-cut (and the probability of the data was actually also high for $K=3$; Figure 2B) but roughly composed of Kopeto-Paeoua-Boulinda-Me Maoya, Me Ori-Bwa Meyu and Mt Do-Mt Mou-Ouinee, respectively. This was congruent with the fact that all populations, except Me Ori-Bwa Meyu and Mt Mou-Ouinee, were significantly differentiated based on exact tests. Based on cpDNA, we also observed the strong divergence of Mt 
Panie, TonNon and Koniambo, as well as the grouping of the three $A$. laubenfelsii at the extremity of a network branch. The level of population differentiation (as measured by mean pairwise $N_{\mathrm{ST}}$ 's) increased both towards the north and the south of the island, leading to a significant Mantel test $(P<0.001)$.

In A. rulei (7 populations) There was no correlation among diversity indices and latitude. A significant deficit of heterozygotes was detected within Bwa Meyu $\left(F_{\mathrm{IS}}=0.131\right)$. Based on nDNA, the most adequate number of clusters was $K=5$, but Structure actually suggested the existence of four genetic groups (Figure $2 \mathrm{C}$ ). Three of them were composed of only one population each, located in the north: Tiebaghi, Paeoua, and PinPin. The fourth group consisted of the central/southern populations Bwa Meyu, Camp des Sapins, Mt Humboldt and Ouinee. Nevertheless, all populations were significantly differentiated based on exact tests. The cpDNA network also showed the divergence of the northernmost Tiebaghi population (Figure 5). However, there was no correlation between genetic and geographic distances, either for nDNA or for cpDNA.

In A. scopulorum (8 populations) There was no correlation between diversity indices and latitude. Three populations showed significant deficits of heterozygotes: Poum, Cap Bocage and Thio ( $F_{\mathrm{IS}}=0.160$ to 0.279 ; Table 1$)$. Nuclear microsatellites evidenced a clear geographic pattern: in Structure, the most likely number of clusters was $K=2$ with Poum, Tiebaghi and Pandop forming a northwestern cluster, while Cap Bocage, Poro, Bogota, Bwa Meyu and Thio formed an eastern cluster (Figure 2D). Only two pairs of populations, belonging to the eastern cluster, were not significantly differentiated according to exact tests: Thio-Poro and Thio-Bwa Meyu. The same geographic pattern was clearly observed on the cpDNA network (Figure 5), and the Mantel test was significant in both cases $(P<0.001)$.

\section{Discussion}

In New Caledonia, Araucaria species are sometimes difficult to distinguish based on morphology and ecology. Our data showed that genetic markers can allow the revision of taxonomic identifications based on field observations and inspection of herbarium specimens. Moreover, although Araucaria trees are emblematic, often dominant in the landscape and supposedly well-known, our results provided new and highly innovative information on species relationships and their evolutionary dynamics.

\section{Genetics allows distinguishing species -although closely related-except $A$. montana and $A$. laubenfelsii}

In contrast to AFLP markers [34], nuclear microsatellites and cpDNA sequencing distinguished most study species.
Species differentiation was especially clear based on cpDNA, a pattern that was expected because this genome is haploid, leading to lower effective size and higher differentiation. However, we observed that $A$. montana and $A$. laubenfelsii were not clearly differentiated based on either nuclear or chloroplast data: i) at nuclear loci, they segregated in somewhat different Structure clusters only after some other, conspecific populations were separated; ii) they shared several cpDNA haplotypes; iii) all $A$. montana and $A$. laubenfelsii populations were grouped in nDNA and cpDNA distance-based networks; and iv) the distinction between the two species accounted for only 0.4 and $17.5 \%$ of the nuclear and chloroplast total genetic variance, respectively, whereas the distinction between other pairs of species explained three to more than ten times more variance. Using the same five nuclear markers as in the present study, Kettle et al. [28] observed up to $35.4 \%$ of the variance between A. columnaris and A. nemorosa, although the two species belong to the same AFLP clade [34]. Araucaria montana and A. laubenfelsii therefore seem to belong to a single gene pool. The Structure analysis and cpDNA network suggested that A. montana and A. laubenfelsii rather form a genetic cline, which may be due to spatial separation given the more southern distribution of $A$. laubenfelsii. The reproductive compatibility between $A$. montana and $A$. laubenfelsii is not known but their morphological distinction appears difficult. Therefore, we suggest that they may be considered as a single species. The subspecies status may nevertheless be justified by their geographic separation and slight genetic differentiation.

\section{Incongruence between nDNA and cpDNA and nDNA admixture suggest introgression and shared ancestral polymorphism}

Interestingly, our results highlighted cases of incongruence between nDNA and cpDNA markers: some individuals possess nDNA predominantly from one species, and a cpDNA haplotype generally associated with another species. Such incongruent patterns could be explained either by gene flow among species (introgression) or by incomplete sorting of ancestral polymorphisms (see e.g. [5,43-45] and references therein).

Reproductive compatibility among New Caledonian species is not known, but our results strongly suggest that hybridization and introgression have occurred in several sites. This is highly probable between $A$. biramulata and A. laubenfelsii in Mt Do, and between $A$. biramulata and A. rulei in Mt Tonta where individuals combine cpDNA haplotypes of one species with multilocus microsatellite nuclear genotypes of the other species. Such introgression has been repeatedly evidenced between conifer species (see e.g. [69-71]). The most likely scenario is that the species first diversified in allopatry and later came into secondary contact and interbred. 
The two species that are suspected of introgression grow in sympatry in Mt Do, which adds credibility to this explanation. The hypothesized introgressing species do not co-occur in Mt Tonta and we cannot exclude the possibility of incomplete sorting of shared ancestral polymorphism (see below). However, A. rulei may have been present in Mt Tonta when among-species gene flow occurred, giving rise to the adult trees that we sampled and that are probably $>100$ years old. Alternatively, introgression in Mt Tonta may result from occasional longdistance transport of pollen grains since $A$. rulei grows in sites that are only a few kilometres distant (e.g. Mt Humboldt; pers. obs. and [38]). Such introgression between - at least nowadays- allopatric populations has already been reported e.g. between Picea mariana and P. rubens in North America [71].

Introgression in Mt Do and Mt Tonta also differ in the genetic signature left in the chloroplast and nuclear genomes relative to the morphological identification of the introgressed trees: in Mt Do, trees were morphologically identified as A. biramulata, possessed A. biramulata cpDNA haplotypes but were predominantly assigned to $A$. laubenfelsii for nDNA. In contrast, in Mt Tonta, trees were morphologically identified as A. biramulata (albeit with some morphological traits more typical of -or intermediate with- $A$. rulei) and predominantly assigned to $A$. biramulata for nDNA, but possessed cpDNA otherwise specific to A. rulei. Since cpDNA is paternally inherited in conifers, this indicates that $A$. biramulata pollen grains fertilized $A$. laubenfelsii ovules in Mt Do, whereas $A$. rulei pollen grains fertilized $A$. biramulata ovules in Mt Tonta. At nuclear loci, that are biparentally inherited, the genetic composition of the introgressed trees was predominantly influenced by one parental species, as opposed to a mixed influence of the two parents: on average, in Mt Do, the A. montana-A. laubenfelsii clusters contributed $76 \%$ to the nuclear genotype of the introgressed individuals, whereas the A. biramulata cluster contribution was only $15 \%$ (although three samples had similar contributions of the A. biramulata and A. montana clusters, and one sample had a predominant contribution of the $A$. biramulata cluster). In Mt Tonta, the $A$. biramulata cluster was largely predominant in the genotype of all introgressed trees, and contributed as much as $88 \%$ to their genotype on average. This suggests, first, that most introgressed trees that we sampled do not belong to the F1 generation, which would show equal contributions from the two parental species, and that hybridization is more ancient. Second, it implies that the initial hybrids backcrossed much more extensively with one parent than with the other one: hybrids would have mostly backcrossed with $A$. laubenfelsii in Mt Do, and with $A$. biramulata in Mt Tonta. This is congruent with the relative abundance of the parental species in the two sites, since $A$. laubenfelsii is dominant in Mt Do (based on our field observations) and A. rulei was not recently observed in Mt Tonta. At each generation, the proportion of the other parent genome in the nucleus of the introgressed tree was halved, ultimately leading to a very low contribution. It is intriguing that such extensive backcrossing with $A$. laubenfelsii, in Mt Do, gave nevertheless rise to trees that were morphologically identified as $A$. biramulata. However, only a very small number of loci may be crucial in bringing about the morphological differences that distinguish the species, and the five loci used here may not be involved in such differences [43].

Hybridization and introgression may also have happened between $A$. montana-A. laubenfelsii and A. biramulata in Pandop (as suggested by the nDNA vs. morphology and cpDNA incongruence of two $A$. montana samples) and between $A$. rulei and A. montana-A. laubenfelsii in Paeoua and Ouinee (as suggested by the cpDNA vs. morphology and nDNA incongruence in one $A$. rulei sample in each site). The involved species co-occur in these geographic locations and, in Pandop, the larger assignment of the putative introgressed samples to $A$. biramulata compared to $A$. montana-A. laubenfelsii based on nuclear data is in agreement with the higher abundance of $A$. biramulata in this site. A lower degree of confidence is associated with the possible cases of introgression in Paeoua and Ouinee, because the putative introgressed samples do not display full genetic (cpDNA haplotype) identity with their potential paternal species $A$. montana-A. laubenfelsii, but only close genetic relatedness. However, it is interesting to note that the population network based on nDNA data indicated close genetic relatedness between the A. montanaA. laubenfelsii and A. rulei populations in Paeoua, and that the Structure analysis showed nuclear admixture between the two species at this site. This would be congruent with the occurrence of hybridization and introgression. Introgression may also have happened in Boulinda, where both species also co-occur and where A. montana- $A$. laubenfelsii samples appeared genetically close to A. rulei based on the nDNA population network, and admixed with A. rulei at nuclear loci based on the Structure analysis.

Introgression may also explain cases of nuclear admixture observed at other geographic locations, although the involved species do not always co-occur. This would suggest a high potential for pollen dispersal across sites, and deserves further investigations.

Another possible explanation for incongruence between chloroplast and nuclear data is the incomplete sorting of shared ancestral polymorphism in one of the two genomes. It is more likely at loci exhibiting a lower degree of variation, and therefore much more plausible in DNA sequences of cpDNA intergenic regions than at nDNA microsatellite loci. Shared cpDNA haplotypes were observed between A. montana, A. biramulata, A. rulei, A. 
muelleri and A. humboldtensis, between A. columnaris and $A$. nemorosa, and even between species that do not belong to the same AFLP clade (A. scopulorum- $A$. biramulata, and A. scopulorum-A. columnaris-A. nemorosa). Some other haplotypes that were previously shared may have gone extinct in some species while not in others. This may be the case e.g. for the $A$. montana haplotypes H11 in Paeoua and H64 in Mt Panie. Shared ancestral polymorphism suggests that species diverged relatively recently, have large effective sizes (delaying the fixation of polymorphisms) and/or experience slow rate of cpDNA sequence evolution $[1,46]$.

\section{Comparative within-species phylogeography: a shared pattern of pronounced population differentiation, in tight relation to their spatial distribution}

We observed a slightly stronger within-species genetic structure than commonly found in outcrossing, windpollinated conifers: nuclear $F_{\mathrm{ST}}$ indices ranged from 0.109 to 0.156 and 10.1 to $12.1 \%$ of the total $\mathrm{nDNA}$ variance was observed among populations, depending on the species, whereas Hamrick et al. [72] reported an average $F_{\mathrm{ST}}$ of 0.073 for various gymnosperms based on allozymes and Petit et al. [73] reported an average $F_{\mathrm{ST}}$ of 0.116 at various biparental markers in conifers. This is most likely explained by the fact that New Caledonian Araucaria species do not conform to the general model of conifers growing as large, wide-ranging populations with no physical barriers over long distances, which usually leads to high gene flow and low differentiation in temperate, northern Hemisphere species (e.g. [74]). In agreement with our results, similar high levels of population differentiation were found in some other tropical conifers (e.g. [75] and references therein) and notably in other Araucaria species: based on RAPD markers, Bekessy et al. [76] estimated that $12.8 \%$ of the total genetic variance was found among populations of $A$. araucana, Pye et al. [77] reported this proportion to be $20.3 \%$ in $A$. cunninghamii and Pye and Gadek [78] observed as much as $37 \%$ of the variation among populations of $A$. bidwillii. In $A$. angustifolia, $19.0 \%$ of the AFLP variance was retrieved among populations [79]. The only estimate based on microsatellite markers in the genus was an among-population variation component of $11.2 \%$ in A. angustifolia [80]. At chloroplast loci, Schlögl et al. [81] estimated $G_{\mathrm{ST}}=0.280$ in $A$. angustifolia, which is slightly higher than our estimates spanning from 0.144 to 0.269. Differentiation levels observed in $A$. montana-A. laubenfelsii, A. biramulata, A. rulei and A. scopulorum were higher than those observed in $A$. columnaris and $A$. nemorosa using the same microsatellite markers $\left(F_{\mathrm{ST}}\right.$ of 0.052 and 0.060 in A. columnaris and A. nemorosa, respectively; [28]). This must at least partly be due to the smaller among-population spatial distances in the latter two species. Here, the relatively strong population differentiation could be related to: i) the complex topology of New Caledonia -with most populations growing in mountain areas separated by valleys- and low pollen and seed dispersal abilities, resulting in low gene flow and long-term isolation of populations; and ii) the occurrence of inbreeding, evidenced by significant $F_{\mathrm{IS}}$ indices, which strengthens the influence of genetic drift.

For all three species examined, we observed a clear geographic structure of the genetic diversity. Three main scenarios could explain this. First, it may result from contemporary gene flow occurring primarily between neighbouring populations. However, rather high $F_{\mathrm{ST}}$ values, significant differentiation of spatially close populations (e.g. the A. montana populations of Paeoua and Kopeto and $A$. scopulorum populations of Thio and Bogota, separated by a distance of less than 5 and $10 \mathrm{~km}$, respectively) and the non-significance of most Mantel tests offer limited support to this hypothesis. Second, different genetic clusters could correspond to groups of populations originating from distinct refugia, where the species would have survived periods of adverse environmental conditions and from which they would have colonized their current geographic ranges when conditions became suitable. A retreat of (at least some) Araucaria species towards refuge areas probably happened during the Quaternary climatic oscillations and genetic divergence could therefore result from prolonged isolation. More genetic, paleontologic and paleoclimatic data are needed to propose hypotheses on the timing and location of potential refugia [30-32]. Third, current populations may be remnants of an ancient, more or less continuous population and intermediate, now extinct populations could have acted as stepping stones for gene flow. This would explain the non-significant difference between $N_{\mathrm{ST}}$ and $G_{\mathrm{ST}}$ in A. montana-A. laubenfelsii and A. rulei (and A. scopulorum when considering northwestern and eastern populations separately, see below). Subsequent fragmentation of the ancestral population could have occurred in response to e.g. competition, erosion of ultramafic soils (that once covered the entire island but now cover only a third of the surface [11]), or more recent human-induced habitat destruction. On the overall distribution area of $A$. scopulorum, we found $N_{\mathrm{ST}}>G_{\mathrm{ST}}$. This suggests that gene flow and common ancestry are not sufficient to counteract the divergence of populations due to mutation. Such a pattern is not unexpected given the highly disjunct distribution of the species, which makes gene flow very unlikely between northwestern and eastern populations.

Some populations displayed especially strong divergence, and the case of the A. montana populations of Mt Panie and TonNon was particularly striking. The divergence of the Mt Panie population was previously reported [34]. The TonNon population grows in the same mountain massif, and the two sites were also characterized by 
low levels of genetic diversity. A founder effect following long-distance dispersal appears unlikely, because populations would be expected to display close relationships with their population(s) of origin, which was not observed. The two populations may originate from specific refugia (possibly two distinct refugia since they are also clearly differentiated from each other), which did not act as sources for colonization elsewhere. They are also spatially very isolated, which likely results in low potential for gene flow and can account for their divergence and low diversity because of genetic drift. In addition, these populations differ by the acidic substrate onto which they grow since all others are found on ultramafic substrates. This could have limited gene flow to even lower levels if the different type of soil prevents the establishment of non-adapted seeds that would migrate from other (ultramafic) sites. We therefore suggest that differential selection in response to distinct soil substrates may have contributed to an even stronger genetic divergence at neutral markers.

At the population level, we observed significant deficit of heterozygotes in eight populations out of 31 . This could be due to the occurrence of null alleles, but we did not observe PCR failure at just one particular locus, as expected in individuals that are homozygous for a null allele. Therefore, the deficit of heterozygotes may rather be explained by the existence of geographic substructure within populations (Wahlund effect) due to selfing or biparental inbreeding following reproduction among related individuals. Such biparental inbreeding was previously shown in $A$. nemorosa [28] and the dioecious A. araucana and $A$. angustifolia $[80,82]$.

\section{Conservation implications}

In the absence of additional data, we suggest that $A$. montana and A. laubenfelsii may be considered as a single evolutionary unit in conservation plans. In contrast, we observed a clear differentiation of the northernmost $A$. montana populations of Mt Panie and TonNon. This may be related to different soil adaptations, and suggests the need to protect these populations as they could represent a distinct Evolutionary Significant Unit (ESU; [83]).

Our data showed strong signs of introgression, involving A. biramulata in particular. Such ancient hybridization events and introgression can be seen as a motor of evolution, potentially given rise to evolutionary novelties [84]. However, A. biramulata grows in only a few sites and the risk of genetic assimilation by more widespread species should be carefully monitored and minimized in order to maintain the species [85].

Last, the negative effects of recent population fragmentation were not detected in the genetic structure of contemporary adult populations, but they may be observed in the future $[28,86]$. Therefore, it appears crucial to protect the habitat of these species that are often found on (or in the immediate vicinity of) open-cast mining sites.

\section{Conclusions}

New Caledonian Araucaria species form a complex of closely related species, which probably diverged recently and/or are characterized by a slow rate of molecular evolution, and among which ancient hybridization and introgression is strongly suspected. Future studies on the evolutionary dynamics of this group should adopt an integrative approach -combining e.g. genetics, ecology and morphology- and simultaneously consider multiple species given their tight relationships and probable gene flow [87]. Mitochondrial markers would be highly valuable since mtDNA is only dispersed by seed movement -which is likely more restricted than pollen movement- and is therefore expected to retain earlier geographic structure $[73,88]$. In order to examine the impact of environmental features on the distribution of genetic diversity within New Caledonia, as many species as possible should be surveyed in a population genetic/phylogeographic framework to allow comparisons and the identification of general trends (comparative phylogeography). The divergence between $A$. montana and A. laubenfelsii should also be assessed based on morphological and ecological characters, in order to confirm or reject our hypothesis that they form a single species. Within $A$. montana, the potential adaptation to different soil substrates (acidic vs. ultramafic) and its influence on genetic differentiation would deserve attention. Last, the hybridization and introgression processes offer many exciting questions to tackle, e.g. how are the introgressed individuals related to their parental species in terms of morphology and ecology? When did hybridization occur, how common were such events and do they still occur nowadays? Could they lead to the emergence of new, self-sustainable and reproductively isolated hybrid species?

\section{Additional file}

Additional file 1: Geographic location and vouchers of the study populations. Herbarium vouchers were deposited at the Herbarium of the Royal Botanic Garden Edinburgh, UK (E).

\section{Competing interests}

The authors declare that they have no competing interests.

\section{Authors' contributions}

MG designed the study, participated in sample collection, carried out the molecular genetic studies, performed the statistical analyses and wrote the manuscript. MFG and PT participated in the sampling and carried out the morphological identifications. RAE participated in the design of the study and sample collection. PMH coordinated the whole project and participated in the design of the study and sample collection. All authors read and approved the final manuscript. 


\section{Acknowledgments}

We are grateful to IRD Nouméa -in particular G. Dagostini, T. Jaffré, J. Munzinger and F. Rigault- for logistical support in the field, and to the Province Sud and Province Nord authorities of New Caledonia for granting collection permits. We also thank all people who provided samples, G. Rouhan for his help throughout the project and contribution to the manuscript, and two anonymous reviewers for helpful comments on a previous version of the manuscript. We acknowledge funding from the ANR project BIONEOCAL and the PPF MNHN 'Structure et évolution des écosystèmes' led by $\mathrm{P}$. Grandcolas. This project was also supported by the network "Bibliothèque du Vivant" funded by the CNRS, the MNHN, the INRA and the CEA (Centre National de Séquençage). All molecular work was performed at the BoEM laboratory of the MNHN.

\section{Author details}

'UMR CNRS-MNHN-UPMC-EPHE 7205 'Institut de Systématique, Evolution, Biodiversité', Muséum National d'Histoire Naturelle, 16 rue Buffon, CP 39, F-75005 Paris, France. ${ }^{2}$ Royal Botanic Garden Edinburgh, Edinburgh EH3 5LR United Kingdom. ${ }^{3}$ Institute of Evolutionary Biology, University of Edinburgh, Ashworth Laboratories, Edinburgh EH3 9JT, United Kingdom.

\section{Received: 6 March 2014 Accepted: 23 July 2014}

Published: 5 September 2014

\section{References}

1. Degnan $J H$, Rosenberg NA: Gene tree discordance, phylogenetic inference and the multispecies coalescent. Trends Ecol Evol 2009, 24:332-340

2. Joly $S$, Bruneau A: Incorporating allelic variation for reconstructing the evolutionary history of organisms from multiple genes: an example from Rosa in North America. Syst Biol 2006, 55:623-636.

3. Linder $\mathrm{CR}$, Rieseberg $\mathrm{LH}$ : Reconstructing patterns of reticulate evolution in plants. Am J Bot 2004, 91:1700-1708.

4. Maddison WP, Knowles LL: Inferring phylogeny despite incomplete lineage sorting. Syst Biol 2006, 55:21-30

5. Pillon Y, Johansen JB, Sakishima T, Roalson EH, Price DK, Stacy EA: Gene discordance in phylogenomics or recent plant radiations, an example from Hawaiian Cyrtandra (Gesneriaceae). Mol Phylogenet Evol 2013, 69:293-298

6. Myers N, Mittermeier RA, Mittermeier CG, da Fonseca GA, Kent J: Biodiversity Hotspots for conservation priorities. Nature 2000 403:853-858.

7. Jaffré $T$, Morat $P$, Veillon J-M, Rigault F, Dagostini G: Composition and Characterisation of the Native Flora of New Caledonia. In Documents Scientifiques et Techniques, Volume II4. New Caledonia: Institut de Recherche pour le Développement Nouméa; 2001:1-121.

8. Grandcolas P, Murienne J, Robillard T, Desutter-Grandcolas L, Jourdan H, Guilbert E, Deharveng L: New Caledonia: a very old Darwinian island? Philos T R Soc B 2008, 363:3309-3317.

9. Espeland M, Murienne J: Diversity dynamics in New Caledonia: towards the end of the museum model? BMC Evol Biol 2011, 11:254.

10. Aitchison JC, Clarke GL, Meffre S, Cluzel D: Eocene arc-continent collision in New Caledonia and implications for regional Southwest Pacific tectonic evolution. Geology 1995, 23:161-164.

11. Pelletier B: Geology of the New Caledonia Region and its Implications for the Study of the New Caledonian Biodiversity. In Compendium of Marine Species of New Caledonia. Documents Scientifiques et Techniques, vol. II7. New Caledonia: Institut de Recherche pour le Développement Nouméa; 2006:19-32

12. Cruaud A, Jabbour-Zahab R, Genson G, Ungricht S, Rasplus J-Y: Testing the ermergence of New Caledonia: Fig wasp mutualism as a case study and a review of evidence. PLoS One 2012, 7:e30941.

13. Pillon Y: Time and tempo of diversification in the flora of New Caledonia. Bot J Linn Soc 2012, 170:288-298.

14. Buerki S, Forest F, Callmander MW, Lowry PP II, Devey DS, Munzinger J: Phylogenetic inference of New Caledonian lineages of Sapindaceae: molecular evidence requires a reassessment of generic circumscriptions. Taxon 2012, 61:109-119.

15. Duangjai S, Samuel R, Munzinger J, Forest F, Wallnöfer B, Barfuss MHJ, Fischer G, Chase MW: A multi-locus plastid phylogenetic analysis of the pantropical genus Diospyros (Ebenaceae), with an emphasis on the radiation and biogeography origins of the New Caledonian endemic species. Mol Phylogenet Evol 2009, 52:602-620.

16. Morat $P$, Jaffré $T$, Tronchet $F$, Munzinger J, Pillon $Y$, Veillon J-M, Chalopin M: The taxonomic database " FLORICAL » and characteristics of the indigenous flora of New Caledonia. Adansonia 2012, 34:177-219.

17. Swenson U, Munzinger J: Taxonomic revision of Pycnandra subgenus Trouettia (Sapotaceae), with six new species from New Caledonia. Aust Syst Bot 2010, 23:333-370.

18. Pascal M, de Forges BR, Le Guyader H, Simberloff D: Mining and other Ttreats to the New Caledonia biodiversity hotspot. Conserv Biol 2008 22:498-499

19. Pillon Y, Munzinger J: Amborella fever and its (little) implication in conservation. Trends Plant Sci 2005, 10:519-520.

20. Barrabé L, Maggia L, Pillon Y, Rigault F, Mouly A, Davis AP, Buerki S: New Caledonian lineages of Psychotria (Rubiaceae) reveal different evolutionary histories and the largest documented plant radiation for the archipelago. Mol Phylogenet Evol 2013, 71:15-35.

21. Eibl JM, Plunkett GM, Lowry PP II: Evolution of Polyscias sect. Tieghemopanax (Araliaceae) based on nuclear and chloroplast DNA sequence data. Adansonia 2001, 23:23-48

22. Pillon Y, Hopkins HCF, Munzinger J, Amir H, Chase MW: Cryptic species, gene recombination, and hybridization in the genus Spiraeanthemum (Cunoniaceae) from New Caledonia. Bot J Linn Soc 2009, 161:137-152.

23. Pillon Y, Munzinger J, Amir H, Hopkins HCF, Chase MW: Reticulate evolution on a mosaic of soils diversification of the NC endemic genus Codia. Mol Ecol 2009, 18:2263-2275.

24. Turner B, Paun O, Munzinger J, Duangjai S, Chase MW, Samuel R: Analyses of amplified fragment length polymorphisms (AFLP) indicate rapid radiation of Diospyros species (Ebenaceae) endemic to New Caledonia. BMC Evol Biol 2013, 13:269.

25. Bottin L, Verhaegen D, Tassin J, Olivieri I, Vaillant A, Bouvet J-M: Genetic diversity and population structure of an insular tree, Santalum austrocaledonicum in New Caledonian archipelago. Mol Ecol 2005, 14:1979-1989

26. Bottin L, Tassin J, Nasi R, Bouvet J-M: Molecular, quantitative and abiotic variables for the delineation of evolutionary significant units: case of sandalwood (Santalum austrocaledonicum Vieillard) in New Caledonia. Conserv Genet 2007, 8:99-109.

27. Herbert J, Hollingsworth PM, Gardner MF, Mill RR, Thomas PI, Jaffré T: Conservation genetics and phylogenetics of New Caledonian Retrophyllum (Podocarpaceae) species. New Zeal J Bot 2002, 40:175-188.

28. Kettle CJ, Hollingsworth PM, Jaffré T, Moran B, Ennos RA: Identifying the early genetic consequences of habitat degradation in a highly threatened tropical conifer, Araucaria nemorosa Laubenfels. Mol Ecol 2007, 16:3581-3591

29. Kurata K, Jaffré T, Setoguchi H: Genetic diversity and geographical structure if the pitcher plant Nepenthes viellardii in New Caledonia; a chloroplast DNA haplotypes analysis. Am J Bot 2008, 95:1632-1644.

30. Poncet V, Munoz F, Munzinger J, Pillon Y, Gomez C, Couderc M, Tranchant-Dubreuil C, Hamon S, de Kochko A: Phylogeography and niche modelling of the relict plant Amborella trichopoda (Amborellaceae) reveal multiple Pleistocene refugia in New Caledonia. Mol Ecol 2013 22:6163-6178

31. Stevenson J, Hope G: A comparison of late Quaternary forest changes in New Caledonia and northeastern Australia. Quaternary Res 2005, 64:382-383

32. Pintaud J-C, Jaffré T, Puig H: Chorology of New Caledonian palms and possible evidence of Pleistocene rain forest refugia. C R Acad Sci 2001, 324:453-463.

33. Hewitt GM: Genetic consequences of climatic oscillations in the Quaternary. Philos T R Soc B 2004, 359:183-195.

34. Gaudeul M, Rouhan G, Gardner MF, Hollingsworth PM: AFLP markers provide insights into the evolutionary relationships and diversification of New Caledonian Araucaria species. Am J Bot 2012, 99:68-81.

35. Proctor J: Vegetation and soil and plant chemistry on ultramafic rocks in the tropical Far East. Perspect Plant Ecol 2003, 6:105-124.

36. Kettle CJ: Conservation Genetics of New Caledonian Araucaria. PhD Dissertation: University of Edinburgh; 2006 
37. Setoguchi H, Osawa TA, Pintaud J-C, Jaffré T, Veillon J-M: Phylogenetic relationship within Araucariaceae based on $r b c \mathrm{~L}$ genes sequences. Am J Bot 1998, 85:1507-1516.

38. de Laubenfels DJ: Gymnospermes. In Flore de la Nouvelle-Calédonie et Dépendances, vol. 4. Paris: Muséum National d'Histoire Naturelle; 1972.

39. Jaffré T, Munzinger J, Lowry PP II: Threats to the conifer species on New Caledonia's ultramafic massifs and proposals for urgently needed measures to improve their protection. Biodivers Conserv 2010 19:1485-1502.

40. Rigg LS, Enright NJ, Jaffré T, Perry GLW: Contrasting population dynamics of the endemic New Caledonian conifer Araucaria laubenfelsii in maquis and rain forest. Biotropica 2005, 42:479-487.

41. Kettle CJ, Ennos RA, Jaffré T, Gardner M, Hollingsworth PM: Cryptic genetic bottlenecks during restoration of an endangered tropical conifer. Biol Conserv 2008, 141:1953-1961.

42. Kettle CJ, Ennos RA, Jaffré T, McCoy S, Le Borgne T, Gardner M, Hollingsworth PM: Importance of demography and dispersal for the resilience and restoration of a critically endangered tropical conifer Araucaria nemorosa. Divers Distrib 2012, 18:248-259.

43. Burgarella C, Lorenzo Z, Jabbour-Zahab R, Lumaret R, Guichoux E, Petit RJ, Soto A, Gil L: Detection of hybrids in nature: application to oaks (Quercus suber and Q. ilex). Heredity 2009, 102:442-452.

44. Krak K, Caklova P, Chrtek J, Fehrer J: Reconstruction of phylogenetic relationships in a highly reticulate group with deep coalescence and recent speciation. Heredity 2013, 110:138-151.

45. Ramadugu C, Pfeil BE, Keremane ML, Lee RF, Maureira-Butler IJ, Roose ML: A six nuclear gene phylogeny of Citrus (Rutaceae) taking into account hybridization and lineage sorting. PLOS One 2013, 8:e68410.

46. Bouillé M, Bousquet J: Trans-species shared polymorphisms at orthologous nuclear gene loci among distant species in the conifer Picea (Pinaceae): implications for the long-term maintenance of genetic diversity in trees. Am J Bot 2005, 92:63-73.

47. Birky CW Jr, Fuerst P, Maruyama T: Organelle gene diversity under migration, mutation, and drift: equilibrium expectations, approach to equilibrium, effects of heteroplasmic cells, and comparison to nuclear genes. Genetics 1989, 121:613-627.

48. Robertson A, Hollingsworth PM, Kettle CJ, Ennos RA, Gardner MF: Characterization of nuclear microsatellites in New Caledonian Araucaria species. Mol Ecol Notes 2004, 4:62-63.

49. Tamura K, Dudley J, Nei M, Kumar S: MEGA4: Molecular Evolutionary Genetics Analysis (MEGA) software version 4.0. Mol Biol Evol 2007, 24:1596-1599.

50. Demesure B, Sodzi N, Petit RJ: A set of universal primers for amplification of polymorphic non-coding regions of mitochondrial and chloroplast DNA in plants. Mol Ecol 1995, 4:129-131.

51. Grivet D, Heinze B, Vendramin GG, Petit RJ: Genome walking with consensus primers: application to the large single copy region of chloroplast DNA. Mol Ecol Notes 2001, 1:345-349.

52. Pritchard JK, Stephens M, Donnelly P: Inference of population structure using multilocus genotype data. Genetics 2000, 155:945-959.

53. Falush D, Stephens M, Pritchard JK: Inference of population structure using multilocus genotype data: linked loci and correlated allele frequencies. Genetics 2003, 164:1567-1587.

54. Earl DA, von Holdt BM: STRUCTURE HARVESTER: a website and program for visualizing STRUCTURE output and implementing the Evanno method. Conserv Genet Resour 2012, 4:359-361.

55. Evanno G, Regnault S, Goudet J: Detecting the number of clusters of individuals using the software STRUCTURE: a simulation study. Mol ECOl 2005, 14:2611-2620.

56. Bryant D, Moulton $\mathrm{V}$ : Neighbor-Net: an agglomerative method for the construction of phylogenetic networks. Mol Biol Evol 2004, 21:255-265

57. Morrison DA: Networks in phylogenetic analysis: new tools for population biology. Int J Parasitol 2005, 35:567-582.

58. Huson DH, Bryant D: Application of phylogenetic networks in evolutionary studies. Mol Biol Evol 2006, 23:254-267.

59. Weir BS, Cockerham CC: Estimating F-statistics for the analysis of population structure. Evolution 1984, 38:1358-1370.

60. Goudet J: FSTAT, version 1.2. A computer program to calculate F-statistics. J Hered 1995, 86:485-486.
61. Excoffier L, Laval G, Schneider S: Arlequin ver. 3.0: an integrated software package for population genetics data analysis. Evol Bioinform 2005, $1: 47-50$.

62. El Mousadik A, Petit RJ: Chloroplast DNA phylogeography of the argan tree of Morocco. Mol Ecol 1996, 5:547-555.

63. Cornuet J-M, Luikart G: Description and power analysis of two tests for detecting recent population bottlenecks from allele frequency data. Genetics 1996, 144:2001-2014.

64. Raymond M, Rousset F: GENEPOP (version 1.2): population genetics software for exact tests and ecumenicism. J Hered 1995, 86:248-249.

65. Ersts PJ: Geographic Distance Matrix Generator (version 1.2.3). [http://biodiversityinformatics.amnh.org/open_source/gdmg]

66. Hardy OJ, Vekemans X: SPAGeDi: a versatile computer program to analyse spatial genetic structure at the individual or population levels. Mol Ecol Notes 2002, 2:618-620.

67. Hardy OJ, Charbonnel N, Fréville H, Heuertz M: Microsatellite allele sizes: a simple test to assess their significance on genetic differentiation. Genetics 2003, 163:1467-1482.

68. Rosenberg N: DISTRUCT: a program for the graphical display of population structure. Mol Ecol Notes 2004, 4:137-138.

69. Du FK, Petit RJ, Liu JQ: More introgression with less gene flow: chloroplast vs. mitochondrial DNA in the Picea asperata complex in China, and comparison with other Conifers. Mol Ecol 2009, 18:1396-1407.

70. Ma X-F, Szmidt AE, Wang X-R: Genetic structure and evolutionary history of a diploid hybrid pine Pinus densata inferred from the nucleotide variation at seven gene loci. Mol Biol Evol 2006, 23:807-816.

71. Perron M, Bousquet J: Natural hybridization between black spruce and red spruce. Mol Ecol 1997, 6:725-734

72. Hamrick JL, Godt MJW, Sherman-Broyles SL: Factors Influencing Levels of Genetic Diversity in Woody Plant Species. In Population Genetics of Forest Trees. Edited by Adams WT, Strauss SH, Copes DL, Griffin AR. Boston: Kluwer Academic Publishers; 1992:95-124.

73. Petit RJ, Duminil J, Fineschi S, Hampe A, Salvini D, Vendramin GG: Comparative organization of chloroplast, mitochondrial and nuclear diversity in plant populations. Mol ECol 2005, 14:189-701.

74. O'Connell LM, Mosseler A, Rajora OP: Extensive long-distance pollen dispersal in a fragmented landscape maintains genetic diversity in white spruce. J Hered 2007, 98:640-645.

75. Aguirre-Planter E, Furnier GR, Eguiarte LE: Low levels of genetic variation and high levels of genetic differentiation among populations of species of Abies from southern Mexico and Guatemala. Am J Bot 2000, 87:362-371.

76. Bekessy SA, Allnutt TR, Premoli AC, Lara A, Ennos RA, Burgman MA, Cortes $M$, Newton AC: Genetic variation in the vulnerable and endemic monkey puzzle tree, detected using RAPDs. Heredity 2002, 88:243-249.

77. Pye MG, Henwood MJ, Gadek PA: Differential levels of genetic diversity and divergence among populations of an ancient Australian rainforest conifer, Araucaria cunninghamii. Plant Syst Evol 2009, 277:173-185.

78. Pye MG, Gadek PA: Genetic diversity, differentiation and conservation in Araucaria bidwillii (Araucariaceae), Australia's Bunya pine. Conserv Genet 2004, 5:619-629.

79. de Souza MIF, Salqueiro F, Carnavale-Bottino M, Félix DB, Alvez-Ferreira M, Bittencourt JVM, Margis R: Patterns of genetic diversity in southern and southeastern Araucaria angustifolia (Bert.) O. Kuntze relict populations. Genet Mol Biol 2009, 32:546-556.

80. Stefenon VM, Gailing O, Finkeldey R: Genetic structure of Araucaria angustifolia (Araucariaceae) populations in Brazil: implications for the in situ conservation of genetic resources. Plant Biology 2007, 9:516-525.

81. Schlögl PS, de Souza AP, Nodari RO: PCR-RFLP analysis of non-coding regions of cpDNA in Araucaria angustifolia (Bert.) O. Kuntze. Genet Mol Biol 2007, 30:423-427.

82. Ruiz E, Gonzalez F, Torres-Diaz C, Fuentes G, Mardones M, Stuessy T, Samuel R, Becerra J, Silva M: Genetic Diversity and differentiation within and among Chilean populations of Araucaria araucana (Araucariaceae) based on allozyme variability. Taxon 2007, 56:1221-1228.

83. Moritz C: Defining 'evolutionary significant units' for conservation. Trends Ecol Evol 1994, 9:373-375.

84. Thompson J, Gaudeul M, Debussche M: Conservation value of sites of hybridization in peripheral populations of rare plant species. Conserv Biol 2010, 24:236-245. 
85. Levin DA, Francisco-Ortega J, Jansen RK: Hybridization and the extinction of rare plant species. Conserv Biol 1996, 10:10-16.

86. Lowe AJ, Boshier D, Ward M, Bacles CFE, Navarro C: Genetic resource impacts of habitat loss and degradation: reconciling empirical evidence and predicted theory for neotropical trees. Heredity 2005, 95:255-273.

87. Semerikov VL, Lascoux M: Nuclear and cytoplasmic variation within and between Eurasian Larix (Pinaceae) species). Am J Bot 2003, 90:1113-1123.

88. Petit RJ, Kremer A, Wagner DB: Finite island model for organelle and nuclear genes in plants. Heredity 1993, 71:630-641.

doi:10.1186/s12862-014-0171-6

Cite this article as: Gaudeul et al:: Evolutionary dynamics of emblematic Araucaria species (Araucariaceae) in New Caledonia: nuclear and chloroplast markers suggest recent diversification, introgression, and a tight link between genetics and geography within species. BMC Evolutionary Biology 2014 14:171.

\section{Submit your next manuscript to BioMed Central and take full advantage of:}

- Convenient online submission

- Thorough peer review

- No space constraints or color figure charges

- Immediate publication on acceptance

- Inclusion in PubMed, CAS, Scopus and Google Scholar

- Research which is freely available for redistribution 